\title{
In Situ Routes to Catalytically Active Ru(0) Species by Reduction of Readily Available, Air-Stable Precursors
}

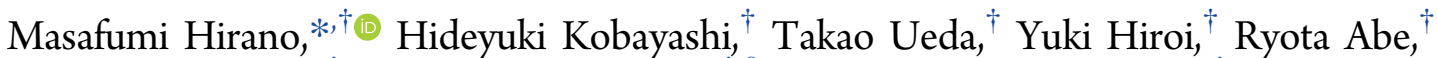 \\ Nobuyuki Komine, ${ }^{\dagger}$ Annie L. Colebatch, ${ }^{\ddagger}, \S$ and Martin A. Bennett*, \\ ${ }^{\dagger}$ Department of Applied Chemistry, Graduate School of Engineering, Tokyo University of Agriculture and Technology, 2-24-16 \\ Nakacho, Koganei, Tokyo 184-8588, Japan \\ ${ }^{\ddagger}$ Research School of Chemistry, Australian National University, Canberra, Australian Capital Territory 0200, Australia
}

\section{Supporting Information}

ABSTRACT: Cross-dimerization of a conjugated diene with a substituted alkene catalyzed by in situ reduction of an air-stable $\mathrm{Ru}(\mathrm{II})$ catalyst precursor has been achieved. Reaction of 2,3-dimethylbutadiene with styrene is catalyzed by $\left[\mathrm{Ru}(\mathrm{acac})_{2}\left(\eta^{4}-1,5-\mathrm{COD}\right)\right](2 \mathrm{a})(5 \mathrm{~mol} \%)$ with $\mathrm{BuLi}(10 \mathrm{~mol} \%)$ at $50{ }^{\circ} \mathrm{C}$ for 6 $\mathrm{h}$ in hexane, giving the cross-dimers in $99 \%$ yield $((E)-4,5$-dimethyl-1-phenylhexa1,4-diene $(3 \mathbf{a}) /(E)$-4,5-dimethyl-1-phenylhexa-2,4-diene $(3 \mathbf{b}) /$ isomers $=84 / 9 / 7)$. Because neither $2 \mathrm{a}$ nor BuLi separately catalyzes the cross-dimerization and

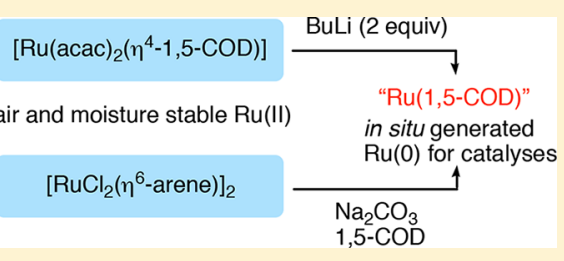
reduction of $2 \mathbf{a}$ with $\mathrm{BuLi}$ in the presence of naphthalene produces $\left[\mathrm{Ru}\left(\eta^{6}\right.\right.$-naphthalene $\left.)\left(\eta^{4}-1,5-\mathrm{COD}\right)\right](\mathbf{1 a})$, the active species in this catalysis is considered to be a $\mathrm{Ru}(0)$ compound. Interestingly, this in situ reduction method of $\mathrm{Ru}(\mathrm{II}) \mathrm{using} \mathrm{BuLi}$ can be applied to the cross-dimerization using an ester such as methyl acrylate. Alternatively, an air-stable Ru(II) complex having a labile arene ligand such as $\left[\mathrm{RuCl}_{2}\left(\eta^{6} \text {-anisole }\right)\right]_{2}(5 \mathrm{c})(5 \mathrm{~mol} \%)$ with $\mathrm{Na}_{2} \mathrm{CO}_{3}(40 \mathrm{~mol} \%)$ in the presence of $1,5-\mathrm{COD}(20 \mathrm{~mol} \%)$ at $100{ }^{\circ} \mathrm{C}$ for $6 \mathrm{~h}$ in 2-butanol also catalyzes the same cross-dimerization in $62 \%$ yield. These protocols provide facile methods for production of unsaturated linear compounds by the cross-dimerization using air-stable $\mathrm{Ru}$ (II) catalyst precursors.

\section{INTRODUCTION}

Catalytic cross-dimerization between conjugated dienes and substituted alkenes is a reliable and promising method for production of linear organic molecules with high atom and step economy. Following the first brief report by Wittenberg of Cocatalyzed cross-dimerizations of dienes, ${ }^{1}$ various catalytic systems based on transition metal compounds from groups 10 to 8 have been reported (Table 1$).^{2-15}$ We have documented regio- and enantioselective cross-dimerizations between conjugated dienes and substituted alkenes catalyzed by

Table 1. Selected Groups 10 to 8 Catalyst Systems for CrossDimerization using Conjugated Dienes/Related Compounds

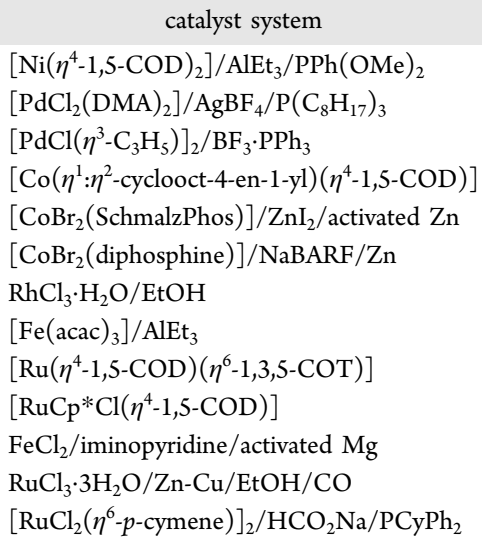

ref

2

$\left[\mathrm{Ru}\left(\eta^{6}\right.\right.$-naphthalene $)\left(\eta^{4}\right.$-cyclic diene $\left.)\right](\mathbf{1}),{ }^{16}$ where the cyclic diene ligand acts as an important ancillary ligand for the activity and selectivity. Typical examples are the cross-dimerization of 1,3-dienes with acrylates, ${ }^{17}$ the tail-to-tail dimerization of acrylates, ${ }^{18}$ and the chemo- and stereoselective cross-dimerization of methyl methacrylate or methacrylamide with unsaturated five-membered-ring compounds. ${ }^{19}$

The detailed mechanism of operation of this catalytic system has been established by isolation/observation of the intermediates, kinetic studies, and DFT calculations. ${ }^{20}$ These reactions are initiated by displacement of the labile $\eta^{6}$ naphthalene ligand to generate a formal " $\mathrm{Ru}$ (cyclic diene)" (A) with a 6 e vacant site, to which a $\eta^{4}$-conjugated compound $(4 \pi)$ and $\eta^{2}$-unsaturated compound $(2 \pi)$ selectively coordinate, and the subsequent $\mathrm{C}-\mathrm{C}$ coupling proceeds by an oxidative coupling mechanism. Scheme 1 outlines the mechanism for the cross-dimerization catalyzed by $\left[\mathrm{Ru}\left(\eta^{6}\right.\right.$-naphthalene $)\left(\eta^{4}-1,5-\right.$ COD)] (1a).

Although this is a potentially useful catalytic system for the cross-dimerization, one must first prepare the thermally unstable and air-sensitive naphthalene complex 1a. For the practical use of this catalysis, it would be desirable to generate in situ catalytically active $\mathrm{Ru}(0)$ species $\mathrm{A}$ by reduction of readily available, air-stable precursors such as $\left[\mathrm{Ru}(\mathrm{acac})_{2}\left(\eta^{4}\right.\right.$ 1,5-COD) $]$ (2a) and $\left[\mathrm{RuCl}_{2}\left(\eta^{6} \text {-arene) }\right]_{2}\right.$ (5) (Scheme 1). In this paper, we report two different methods for the facile

Received: December 11, 2017

Published: March 27, 2018 
Scheme 1. Outline of Catalytic Linear Cross-Dimerization of Diene with Alkene

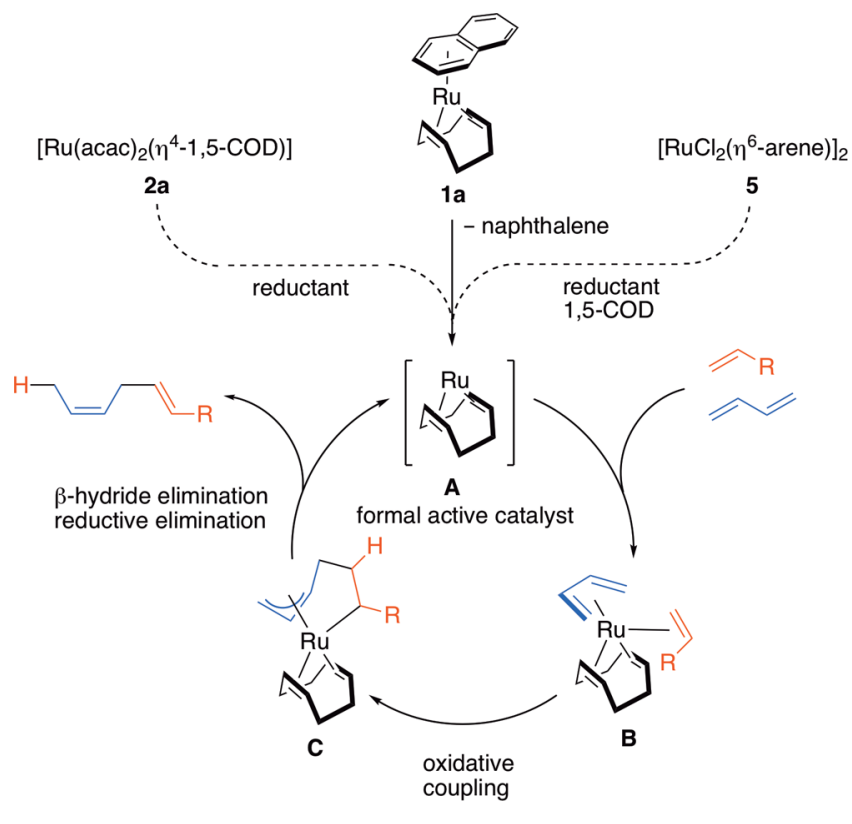

generation of the " $\mathrm{Ru}(1,5-\mathrm{COD})$ " and related " $\mathrm{Ru}($ cyclic diene)" species by in situ reduction of ruthenium(II) compounds.

\section{RESULTS AND DISCUSSION}

In Situ Reduction of [Ru(acac) $\left.)_{2}\left(\eta^{4}-1,5-C O D\right)\right](2 a)$ as the Catalyst Precursor. A series of $\left[\mathrm{Ru}(\mathrm{acac})_{2}\left(\eta^{4}\right.\right.$-cyclic diene)] (2) complexes is readily prepared by treatment of $\left[\mathrm{Ru}(\mathrm{acac})_{3}\right]$ with cyclic dienes in the presence of $\mathrm{Zn}$ in wet THF. ${ }^{21}$ We focused on the air- and moisture-stable compound $\left[\mathrm{Ru}(\mathrm{acac})_{2}\left(\eta^{4}-1,5-\mathrm{COD}\right)\right](\mathbf{2 a})$ as a catalyst precursor for the present cross-dimerization. We employed the cross-dimerization of 2,3-dimethylbutadiene with styrene as a model reaction, because this reaction is catalyzed by the $\mathrm{Ru}(0)$ complex $\left[\mathrm{Ru}\left(\eta^{6}\right.\right.$ naphthalene $\left.)\left(\eta^{4}-1,5-\mathrm{COD}\right)\right]$ (1a) and the reaction mechanism is well-established. ${ }^{20 a}$ Table 2 illustrates the results of screening of several reductants for 2a. In this catalysis, the major and primary minor products were $(E)-\mathbf{3 a}$ and $(E)-\mathbf{3 b}$, respectively. We also detected several minor isomers having the same molecular weight as 3 by GC/GC-MS analyses, but their detailed structures are still unclear. The divalent $\mathrm{Ru}$ complex $2 \mathrm{a}$ precursor alone showed no catalytic activity (entry 1).

A reductant was therefore required to generate a $\mathrm{Ru}(0)$ species, but $\mathrm{Mg}$ metal did not work at all (Table 2, entry 2). More active metal powders, prepared by a reduction of the corresponding anhydrous metal chloride with an alkali metal such as $\mathrm{K}, \mathrm{Na}$, and $\mathrm{Li}$, are known as Rieke metals. ${ }^{22}$ However, both Rieke $\mathrm{Mg}\left(\mathrm{Mg}^{*}\right)$ and Rieke $\mathrm{Zn}\left(\mathrm{Zn}^{*}\right)$ were very inefficient (entries 3 and 4). Sodium/naphthalene and lithium/ naphthalene yielded the cross-dimers in moderate yields (entries 5 and 6). Among the hydride reagents screened, $\mathrm{LiAlH}_{4}$ gave the desired cross-dimers in promising yield (entry 8), although $\mathrm{NaBH}_{4}$ was almost ineffective (entry 7). Alkylmetal reagents such as $\mathrm{MeLi}$ and $\mathrm{BuLi}$ furnished the cross-dimers in good yields (entries 12 and 13). We focused on $\mathrm{BuLi}$, as a mild reductant with low nucleophilicity, for reduction of $2 \mathrm{a}$.
Table 2. Screening of Reductants for $\left[\mathrm{Ru}(\mathrm{acac})_{2}\left(\eta^{4}-1,5-\right.\right.$ COD)] $(2 \mathrm{a})^{a}$

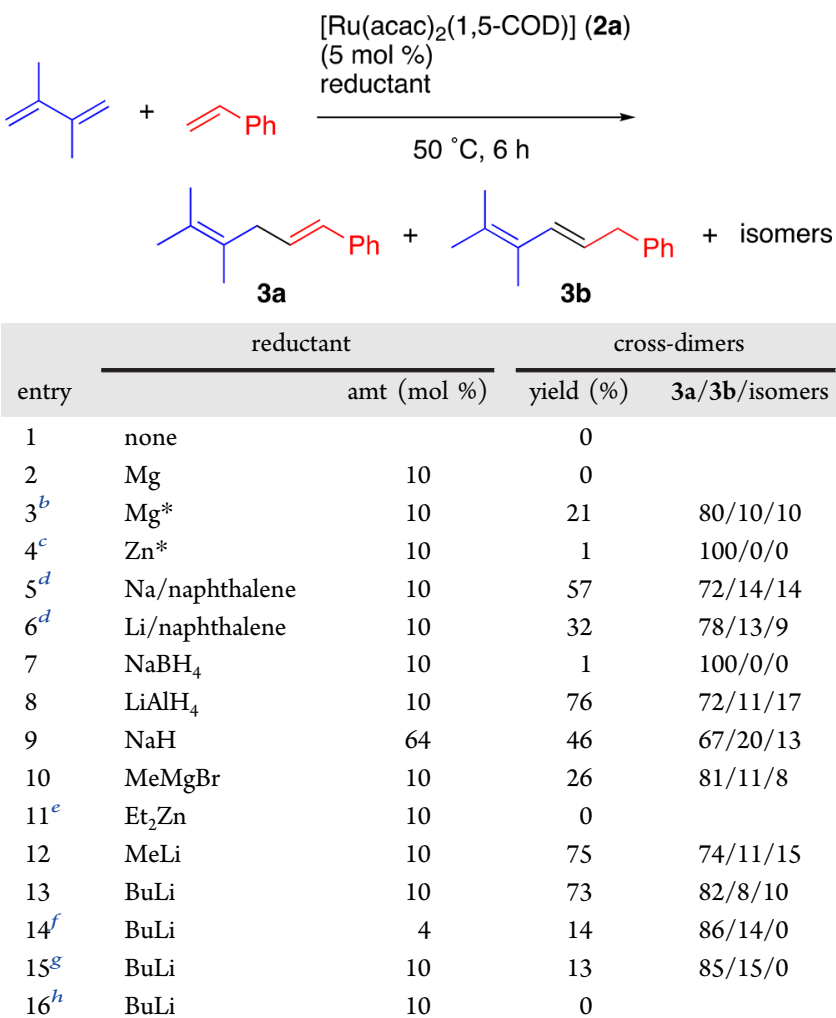

${ }^{a_{T}}$ Typical conditions: 2a $(0.05 \mathrm{mmol})$, 2,3-dimethylbutadiene (1.0 $\mathrm{mmol})$, styrene $(1.0 \mathrm{mmol})$, hexane $(1.5 \mathrm{~mL}), 50^{\circ} \mathrm{C}, 6 \mathrm{~h}$. Yields and ratios of the cross-dimers were determined by GLC analysis. ${ }^{b}$ Rieke $\mathrm{Mg} .{ }^{c}$ Rieke $\mathrm{Zn} .{ }^{d} \mathrm{Metal} /$ naphthalene was prepared in another vessel and was transferred into the catalytic system by a cannula tube. ${ }^{e}[2,3-$ dimethylbutadiene $] /[$ styrene $]=2 / 1 .{ }^{f_{\mathbf{2 a}}}(2 \mathrm{~mol} \%) .{ }^{g}$ Temperature 30 ${ }^{\circ} \mathrm{C} .{ }^{h}$ In the absence of $2 \mathrm{a}$.

The optimized conditions for the cross-dimerization of 2,3dimethylbutadiene with styrene catalyzed by $2 \mathrm{a}(5 \mathrm{~mol} \%)$ and $\mathrm{BuLi}$ were established; the results are given in Table 3 . The optimal $\mathrm{BuLi} / 2 \mathrm{a}$ ratio was found to be $2 / 1$, which gave crossdimers in $87 \%$ yield. The yield was reduced slightly, to $81 \%$, by use of a $\mathrm{BuLi} / 2$ a ratio of $4 / 1$, but use of a large excess of $\mathrm{BuLi}$ (8 equiv) stopped the reaction completely (entry 4 ), probably because of competing anionic polymerization of 2,3-dimethylbutadiene and/or styrene. Finally, a slight excess of 2,3dimethylbutadiene over styrene, with $10 \mathrm{~mol} \% \mathrm{BuLi}$, furnished the cross-dimers almost quantitatively (entry 9).

Because the yield and distribution of the products by this catalysis (Table 3, entry 7) are similar to those observed in the $\mathrm{Ru}(0)$-catalyzed reaction (entry 9), the $2 \mathrm{a} / \mathrm{BuLi}$ system is likely to act by the same mechanism as $\mathbf{1 a}$.

The GLC analysis for reduction of $\mathbf{2 a}$ with 2 equiv of $\mathrm{BuLi}$ in hexane showed evolution of butane (17.6\%), 1-butene $(5.0 \%)$, (E)-2-butene (1.8\%), and octane (6.9\%), and (Z)-2-butene was not observed. This observation supports formation of a $\mathrm{Ru}(0)$ species by the in situ reduction. Although the present data suggest that this system reduces a limited amount of $\mathrm{Ru}(\mathrm{II})$ species, further addition of BuLi does not improve the catalysis (Table 3). In another effort to obtain evidence for generation of a $\mathrm{Ru}(0)$ species by this in situ reduction, we performed the stoichiometric reaction of $2 \mathrm{a}$ with 2 equiv of $\mathrm{BuLi}$ in the presence of naphthalene. The $\mathrm{Ru}(0)$ complex $\left[\mathrm{Ru}\left(\eta^{6}-\right.\right.$ 
Table 3. Optimizations for Reaction of 2,3Dimethylbutadiene with Styrene ${ }^{a}$

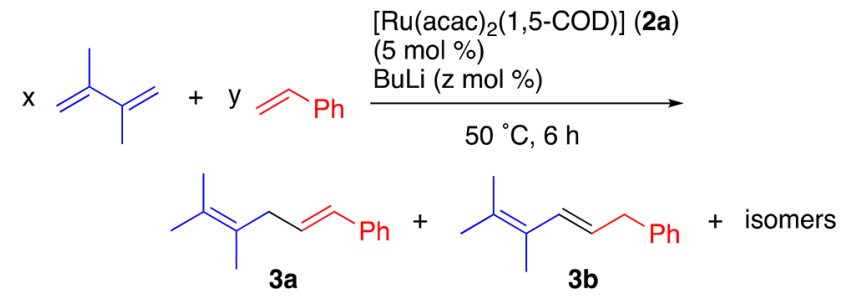

\begin{tabular}{cccccc} 
& \multicolumn{2}{c}{ amt $(\mathrm{mol} \%)$} & & \multicolumn{2}{c}{ cross-dimers } \\
\cline { 2 - 3 } \cline { 5 - 6 } entry & $x / y$ & $z$ & & yield $(\%)$ & $3 \mathbf{3 a} / \mathbf{3 b} /$ isomers \\
1 & $2 / 1$ & 5 & & 80 & $84 / 9 / 7$ \\
2 & $2 / 1$ & 10 & & 87 & $83 / 10 / 7$ \\
3 & $2 / 1$ & 20 & & 81 & $80 / 9 / 11$ \\
4 & $2 / 1$ & 40 & & 0 & \\
5 & $1 / 3$ & 10 & & 81 & $62 / 31 / 7$ \\
6 & $1 / 2$ & 10 & & 82 & $65 / 26 / 9$ \\
7 & $1 / 1$ & 10 & & 73 & $82 / 8 / 10$ \\
8 & $3 / 1$ & 10 & & 99 & $84 / 9 / 7$ \\
$9^{b}$ & $1.2 / 1$ & 0 & & 84 & $79 / 13 / 8$
\end{tabular}

${ }^{a}$ Conditions unless specified otherwise: 2a $(0.05 \mathrm{mmol}), 2,3-$ dimethylbutadiene (1.04-2.99 mmol), styrene (1.04-2.96 mmol), in $\operatorname{BuLi}(0.049-0.396 \mathrm{mmol})$, hexane $(1.5 \mathrm{~mL})$, temperature $50{ }^{\circ} \mathrm{C}$, time $6 \mathrm{~h}$. Yields and product ratios were determined by GLC analysis. ${ }^{b}$ Conditions: 1a $(0.03 \mathrm{mmol}), 2,3$-dimethylbutadiene $(1.77 \mathrm{mmol})$, styrene $(1.48 \mathrm{mmol})$, temperature $50{ }^{\circ} \mathrm{C}$, time $5 \mathrm{~h}$.

naphthalene $\left.)\left(\eta^{4}-1,5-\mathrm{COD}\right)\right]$ (1a) was certainly produced, although it was obtained in only $8 \%$ yield (eq 1 ) and the

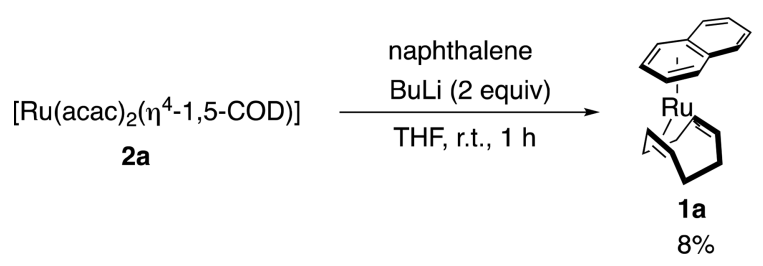

other products were not well characterized. We know little about the course of reaction. However, 2a was almost completely consumed and very broad resonances were observed in the aliphatic region in the ${ }^{1} \mathrm{H}$ NMR spectrum. It appears that a ruthenium(0) species was formed under the reaction conditions, among other unidentified products.

Synthesis of and Cross-Dimerization by $\left[\mathrm{Ru}(\mathrm{acac})_{2} \mathrm{~L}\right]$ (2) as the Catalyst Precursor. With the optimized conditions for reduction of $2 \mathrm{a}$ in hand, we explored the scope of the catalyst $\left[\mathrm{Ru}(\mathrm{acac})_{2} \mathrm{~L}\right](2)(5 \mathrm{~mol} \%)$ in the presence of $\mathrm{BuLi}$ $(10 \mathrm{~mol} \%)$. A series of new $\left[\mathrm{Ru}(\mathrm{acac})_{2} \mathrm{~L}\right]$ complexes $(\mathrm{L}=2$ phenylbicyclo[3.3.1] nona-2,6-diene (L2), 2,5-dimethyl-7,8(tetrafluorobenzo)bicyclo[2.2.2] octatriene (L3), (3,5-dioxa-4phosphacyclohepta $\left[2,1-a: 3,4-a^{\prime}\right]$ dinaphthalen-4-yl)iminostilbene (L4)) was prepared from $\left[\mathrm{Ru}(\mathrm{acac})_{3}\right]$ according to our previous method (eq 2)..$^{21}$ Oligomeric complexes $\left[\mathrm{Ru}(\mathrm{acac})_{2}\left(\mu_{2}, \kappa^{1} \mathrm{P}-\mathrm{L}\right)_{2}\right]_{n}$ are formed initially in the case of $\mathrm{L}=$ dppe, dppp under these conditions, and heating to $140{ }^{\circ} \mathrm{C}$ is required to convert them into monomeric cis-[Ru$\left.(\mathrm{acac})_{2} \mathrm{~L}\right]^{21 \mathrm{~b}, 23}$ However, $\left[\mathrm{Ru}(\mathrm{acac})_{3}\right]$ in the presence of $\mathrm{Zn}$ reacted with dcype in refluxing THF to give cis-[Ru$(\text { acac })_{2}$ (dcype) (2e) directly, although in only moderate yield (16\%). More efficient access to 2 e ( $80 \%$ yield) was

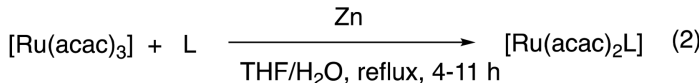

$$
\begin{aligned}
& L=L 2(\mathbf{2 b}, 81 \%) \\
& \text { L3 (2c, 79\%) } \\
& \text { L4 (2d, 88\%) } \\
& \text { L5 (2e, 16\%) }
\end{aligned}
$$

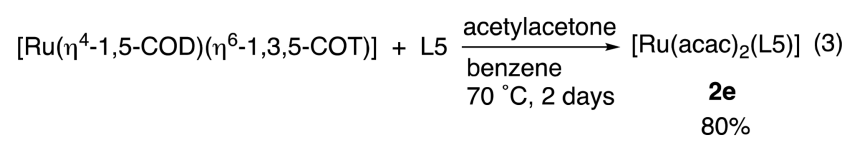

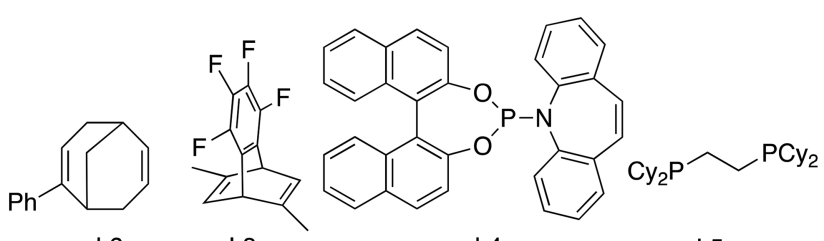

L2

L3

L4

L5

provided by the treatment of $\left[\mathrm{Ru}\left(\eta^{4}-1,5-\mathrm{COD}\right)\left(\eta^{6}-1,3,5-\right.\right.$ COT) ] with dcype and acetylacetone at $70{ }^{\circ} \mathrm{C}$ (eq 3 ).

Single crystals suitable for X-ray analysis were obtained by recrystallization from acetone/hexane for $\mathbf{2 b}$ and from THF/ hexane for $\mathbf{2 c , d}$, respectively (Figure 1). Although complexes 2 bearing an unsymmetrical bidentate ligand potentially produce a diastereomeric mixture arising from the $\Delta$ and $\Lambda$ forms of the two chelating acac ligands, the single crystals of $\mathbf{2 b}-\mathbf{d}$ were obtained as single diastereomers of $\mathrm{rac}-\Lambda-\mathbf{2 b}$, rac- $\Delta-\mathbf{2} \mathbf{c}$, and $\mathrm{rac}$ $\Delta$-2d. Knowing the X-ray structures, we could determine the diastereomer ratios of the original samples of $\mathbf{2 b}-\mathbf{d}$ from the NMR data to be $\mathrm{rac}-\Delta-\mathbf{2 b} / \mathrm{rac}-\Lambda-2 \mathbf{b}=62 / 38, \mathrm{rac}-\Delta-2 \mathrm{c} / \mathrm{rac}-\Lambda$ $2 \mathrm{c}=85 / 15$, and $\mathrm{rac}-\Delta-(S)-\mathbf{2 d} / \mathrm{rac}-\Lambda-(S)-\mathbf{2 d}=79 / 21$, respectively.

Under the optimized conditions, cross-dimerization between 2,3-dimethylbutadiene and styrene was catalyzed by the in situ reduction of $2 / \mathrm{BuLi}$ (Table 4 ), the process being most efficient for $\mathbf{2 a}$. The cross-dimerization was also catalyzed by $\mathbf{2 b} / \mathrm{BuLi}$ and $2 \mathrm{c} / \mathrm{BuLi}$ in moderate yields (entries 2 and 3 ), but the product yield was much lower in the case of $\mathbf{2 d} / \mathrm{BuLi}$ (entry 4 ), while the system $\left[\mathrm{Ru}(\mathrm{acac})_{2}(\mathrm{dcype})\right](\mathbf{2 e})$ gave no cross-dimer at all. Note that although $\left[\mathrm{Ru}\left(\eta^{6}\right.\right.$-naphthalene $\left.)\left(\eta^{4}-1,5-\mathrm{COD}\right)\right]$ $(\mathbf{1 a})^{24}$ is readily obtained by treatment of $\left[\mathrm{Ru}(\mathrm{acac})_{2}\left(\eta^{4}-1,5-\right.\right.$ COD)] (2a) with 2 equiv of sodium naphthalene, ${ }^{24 a}$ all attempts to prepare the corresponding $\left[\mathrm{Ru}\left(\eta^{6}\right.\right.$-naphthalene $\left.) \mathrm{L}\right]$ complexes from $\mathbf{2 b}(\mathrm{L}=2$-phenylbicyclo[3.3.1] nona-2,6-diene (L2)), 2c $(\mathrm{L}=2,5$-dimethyl-7,8-(tetrafluorobenzo)bicyclo[2.2.2] octatriene (L3)), and $2 \mathrm{~d}(\mathrm{~L}=$ (3,5-dioxa-4phosphacyclohepta $\left[2,1-a: 3,4-a^{\prime}\right]$ dinaphthalen-4-yl)iminostilbenzene (L4)) failed even at low temperature; thus, their catalytic behavior could not be examined.

No cross-dimers were obtained when BuLi was added to a mixture of 2,3-dimethylbutadiene and methyl acrylate in hexane containing the catalyst precursor $\mathbf{2 a}$ (Table 5, entry 1), probably owing to the undesirable competing reaction of $\mathrm{BuLi}$ with methyl acrylate. However, when 2,3-dimethylbutadiene and methyl acrylate were added after pretreatment of $2 \mathrm{a}(5 \mathrm{~mol}$ $\%)$ with $\mathrm{BuLi}(10 \mathrm{~mol} \%)$ for $1 \mathrm{~h}$ at room temperature, the result was more promising, the cross-dimers being obtained in $35 \%$ yield (entry 2 ). In THF, under the same conditions with the pretreatment, the cross-dimers were obtained almost quantitatively (entry 4).

The results obtained with a range of catalyst precursors under optimized conditions are shown in Table 6. In this 
(A)

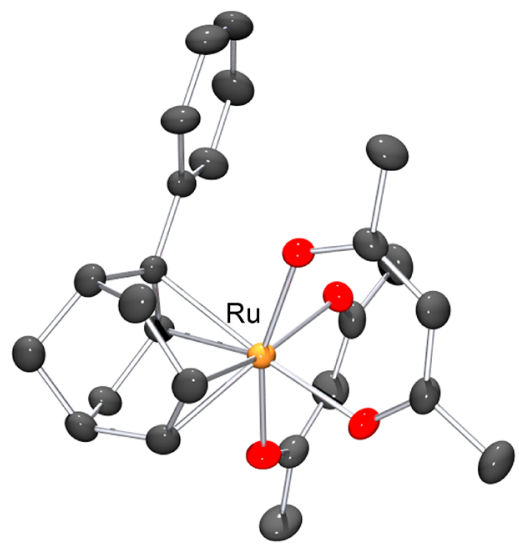

(B)

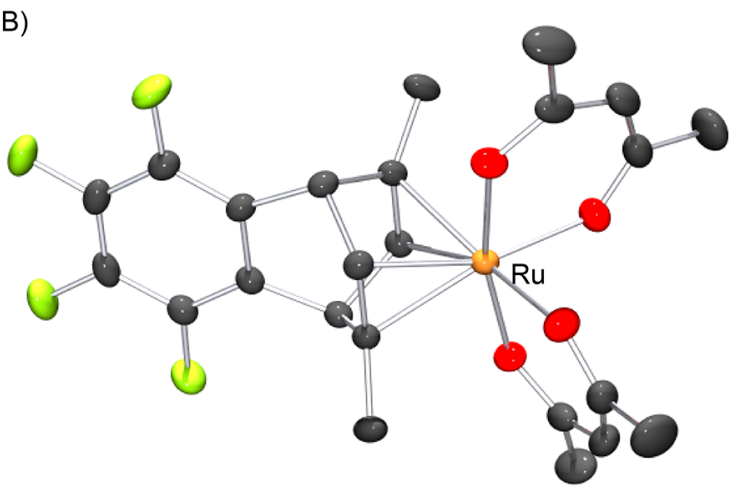

(C)

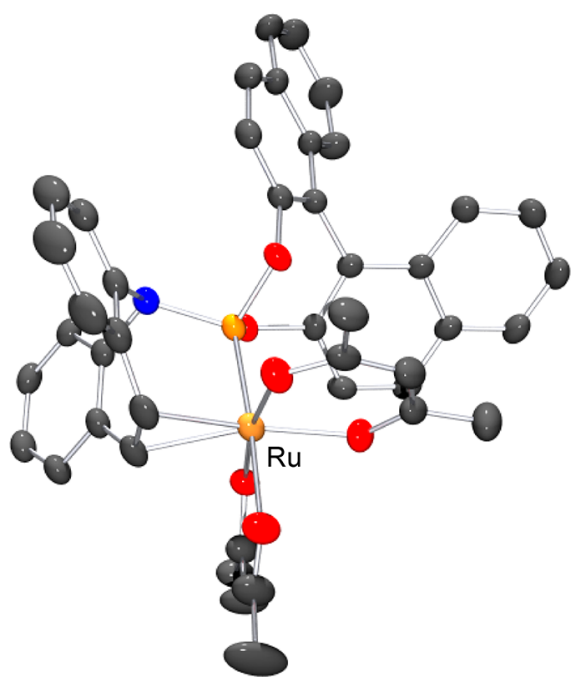

Figure 1. Molecular structures determined by single-crystal X-ray diffraction for $\Lambda-2 b(\mathrm{~A}), \Delta-2 \mathrm{c}$ (B), and $\Delta-\mathbf{2 d}$ (C). All hydrogen atoms and incorporated molecules are omitted for clarity. Ellipsoids represent $50 \%$ probability.

reaction, the major product was (E)-4a along with $(Z)-\mathbf{4 a}$ and $\mathbf{4} \mathbf{b}$ as the prime minor products. The GC/GC-MS analyses also suggested formation of isomers having the same molecular weight as $\mathbf{4}$, but their detailed structures are unknown. When a slight excess of methyl acrylate was used, the reaction occurred in excellent yield (entry 1), but an increase in the amount of 2,3-dimethylbutadiene decreased the product yield (entry 2). As in the 2,3-dimethylbutadiene/styrene cross-dimerization, complex 2a showed the highest activity of these precursors.

Synthesis of and Cross-Dimerization by $\left[\mathrm{Ru}\left(\eta^{6}\right.\right.$-arene)$\left.\left(\eta^{4}-1,5-C O D\right)\right](1)$. We examined initially the catalytic ability of
Table 4. Cross-Dimerization of 2,3-Dimethylbutadiene with Styrene Catalyzed by $\left[\mathrm{Ru}(\operatorname{acac})_{2} \mathrm{~L}\right] / \mathrm{BuLi}^{a}$

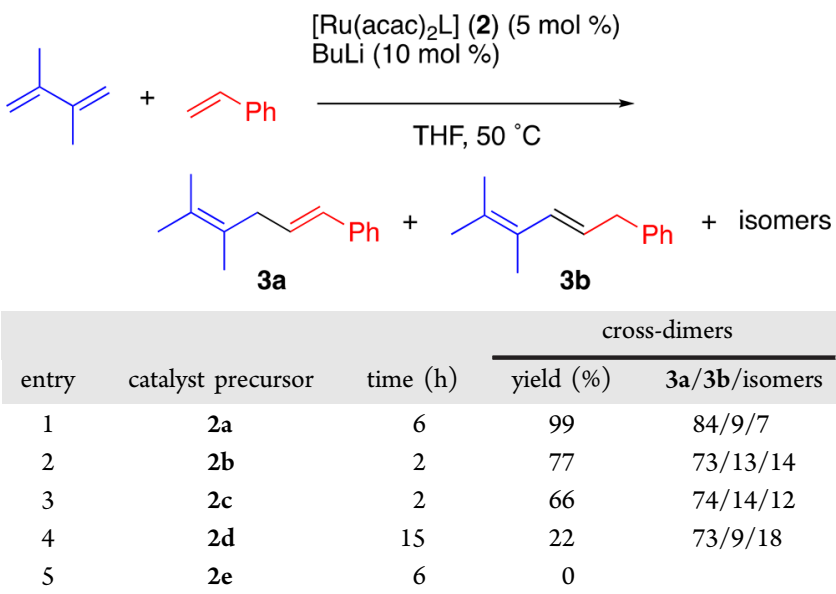

${ }^{a}$ Conditions: 2a-e (0.0398-0.0500 mmol), BuLi (0.10 mmol), 2,3dimethylbutadiene $(1.49-2.11 \mathrm{mmol})$, styrene (1.00-1.04 mmol), THF (1.5 mL).

Table 5. Cross-Dimerization of 2,3-Dimethylbutadiene with Methyl Acrylate Catalyzed by $\left[\mathrm{Ru}(\mathrm{acac})_{2}(1,5-\mathrm{COD})\right](2 \mathrm{a}) /$ $\mathrm{BuLi}^{a}$
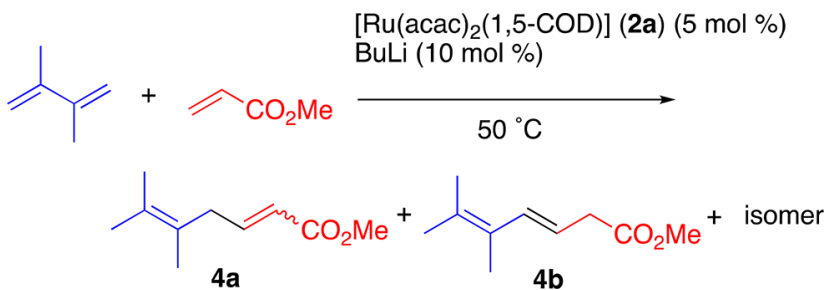

\begin{tabular}{|c|c|c|c|c|c|}
\hline \multirow[b]{2}{*}{ entry } & \multirow[b]{2}{*}{ solvent } & \multirow[b]{2}{*}{$\begin{array}{l}\text { pretreatment } \\
\text { (h) }\end{array}$} & \multirow[b]{2}{*}{$\underset{(\mathrm{h})}{\operatorname{time}}$} & \multicolumn{2}{|c|}{ cross-dimers } \\
\hline & & & & $\begin{array}{c}\text { yield } \\
(\%)\end{array}$ & $\begin{array}{c}E-4 a / Z-4 a / 4 b / \\
\text { isomers }\end{array}$ \\
\hline 1 & hexane & 0 & 6 & 0 & \\
\hline $2^{b}$ & hexane & 1 & 6 & 35 & $74 / 20 / 6 / 0$ \\
\hline 3 & THF & 0 & 6 & 65 & $67 / 9 / 22 / 2$ \\
\hline $4^{b}$ & THF & 1 & 4 & 97 & $69 / 8 / 21 / 2$ \\
\hline $5^{b}$ & toluene & 1 & 10 & 41 & $68 / 17 / 12 / 3$ \\
\hline $6^{b}$ & benzene & 1 & 10 & 57 & $75 / 14 / 9 / 2$ \\
\hline
\end{tabular}

${ }^{a}$ Conditions: 2a (0.0498-0.0506 mmol), BuLi (0.093-0.10 mmol), 2,3-dimethylbutadiene (1.05 mmol), methyl acrylate (1.56 mmol), temperature $50{ }^{\circ} \mathrm{C}$. Yields and product ratios were determined by GLC analysis. ${ }^{b}$ The substrates were added after pretreatment of $\mathbf{2 a}$ with $\mathrm{BuLi}$ for $1 \mathrm{~h}$ at room temperature.

a series of $\left[\mathrm{Ru}\left(\eta^{6}\right.\right.$-arene $\left.)\left(\eta^{4}-1,5-\mathrm{COD}\right)\right]$ complexes, analogous to the naphthalene compound, which, if the arene is sufficiently labile, are potential precursors to a coordinatively unsaturated "Ru( $\left.\eta^{4}-1,5-\mathrm{COD}\right) "$ species. ${ }^{24}$ If the $\left[\mathrm{RuCl}_{2}\left(\eta^{6} \text {-arene }\right)\right]_{2}$ complex is readily available starting from $\mathrm{RuCl}_{3}$, it can be converted into $\left[\mathrm{Ru}\left(\eta^{6}\right.\right.$-arene $\left.)\left(\eta^{4}-1,5-\mathrm{COD}\right)\right]$ by treatment with $1,5-\mathrm{COD}$ in 2-propanol or ethanol in the presence of anhydrous $\mathrm{Na}_{2} \mathrm{CO}_{3}$. This procedure has been used for the $\mathrm{C}_{6} \mathrm{Me}_{6},{ }^{25,26} \mathrm{p}$ cymene, ${ }^{27,28}$ and benzene ${ }^{28}$ complexes. More versatile procedures employ labile ruthenium(0) systems as starting materials: e.g. $\left[\mathrm{Ru}\left(\eta^{4}-1,5-\mathrm{COD}\right)\left(\eta^{6}-1,3,5-\mathrm{COT}\right)\right]$ with an arene in the presence of hydrogen ${ }^{29}$ or $\left[\mathrm{Ru}\left(\eta^{6}\right.\right.$-naphthalene $)\left(\eta^{4}-1,5-\right.$ COD) ] (1a) with an arene in the presence of acetonitrile. ${ }^{24} \mathrm{We}$ used the second method to make the complexes of benzene (1b), anisole (1c), dimethylaniline (1d), acetophenone (1e) 
Table 6. Cross-Dimerization of 2,3-Dimethylbutadiene with Methyl Acrylate Catalyzed by $\left[\mathrm{Ru}(\mathrm{acac})_{2}(\mathrm{~L})\right](2) / \mathrm{BuLi}$ in THF $^{a}$

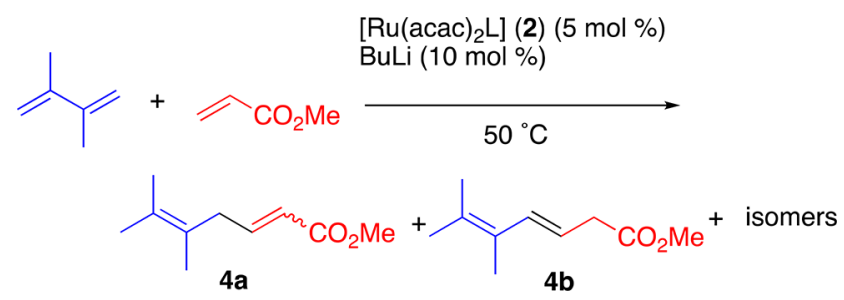

\begin{tabular}{ccccc} 
& & & \multicolumn{2}{c}{ cross-dimers } \\
entry & catalyst precursor & time $(\mathrm{h})$ & yield $(\%)$ & E-4a/Z-4a/4b/isomers \\
\cline { 1 - 3 } $\mathbf{1}^{b}$ & 2a & 4 & 97 & $69 / 8 / 21 / 2$ \\
2 & 2a & 4 & 63 & $81 / 3 / 14 / 2$ \\
3 & 2b & 6 & 10 & $90 / 0 / 10 / 0$ \\
4 & 2c & 3 & 46 & $78 / 4 / 18 / 0$ \\
5 & 2d & 4 & 49 & $74 / 18 / 8 / 0$
\end{tabular}

${ }^{a}$ Conditions: $2(0.0487-0.0506 \mathrm{mmol}), \mathrm{BuLi}(0.10 \mathrm{mmol})$, pretreatment $1 \mathrm{~h}$ at room temperature, 2,3-dimethylbutadiene (2.02-2.11 $\mathrm{mmol})$, methyl acrylate $(1.00 \mathrm{mmol})$, temperature $50{ }^{\circ} \mathrm{C}$.Yields and product ratios were determined by GLC. ${ }^{b} 2,3$-Dimethylbutadiene $(1.05 \mathrm{mmol})$ and methyl acrylate $(1.56 \mathrm{mmol})$ were used for the catalysis.

and 1,2-, 1,3-, and 1,4-dimethoxybenzene (1f-h, respectively); complexes $\mathbf{1 b}, \mathbf{c}$ had already been made by the first method (Chart 1). ${ }^{29}$ They were characterized by ${ }^{1} \mathrm{H}$ and ${ }^{13} \mathrm{C}$ NMR spectroscopy and elemental analysis and by X-ray analyses for 1d,g,h.

\section{Chart 1}
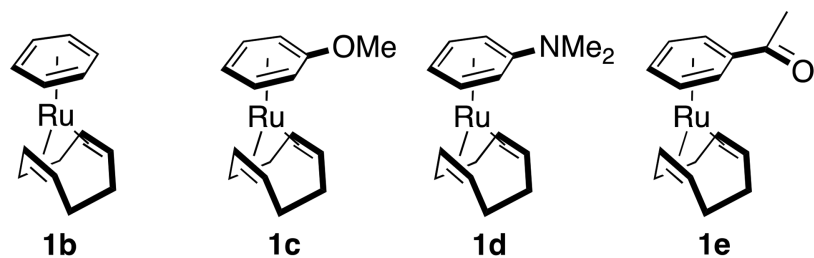

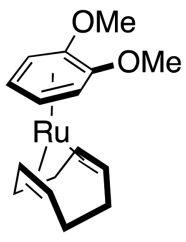

$1 f$

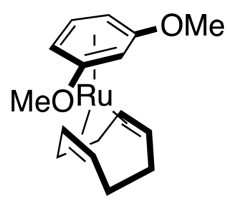

$1 \mathrm{~g}$

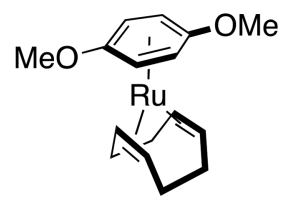

1h
The molecular structures of $\mathbf{1 d , g , h}$ determined by X-ray analysis are depicted in Figure 2, and the $\mathrm{Ru}-\mathrm{C}$ (arene) distances are given in Table 7 . In the reported structure of $\mathbf{1 b}$, the $\mathrm{Ru}-\mathrm{C}$ (arene) distances fall in the range 2.199(7)-2.261(7) $\AA \AA^{30}$ Similar $\mathrm{Ru}-\mathrm{C}$ (arene) distances to the unsaturated carbon atoms are observed in $\mathbf{1 d}, \mathbf{g}, \mathbf{h}$, but some of the $\mathrm{Ru}-\mathrm{C}$ (ipso) distances in $\mathbf{1 g}, \mathbf{h}$ are slightly above this range $(\mathrm{Ru}-\mathrm{C}(3)$ in $\mathbf{1 g}$ 2.304(6) $\AA$; $\mathrm{Ru}-\mathrm{C}(4)$ in $\mathbf{1 h} 2.310(4) \AA$ ), while in $\mathbf{1 d}$ the $\mathrm{Ru}-$ $\mathrm{C}(1)$ distance of 2.385(3) $\AA$ to the ipso carbon atom bearing the strongly electron-donating substituent $\mathrm{NMe}_{2}$ is well above the range.

The catalytic activities of $\left[\mathrm{Ru}\left(\eta^{6}\right.\right.$-arene $\left.)\left(\eta^{4}-1,5-\mathrm{COD}\right)\right](\mathbf{1})$ for cross-dimerization between 2,3-dimethylbutadiene with methyl acrylate were tested; the results are shown in Table 8.
(A)

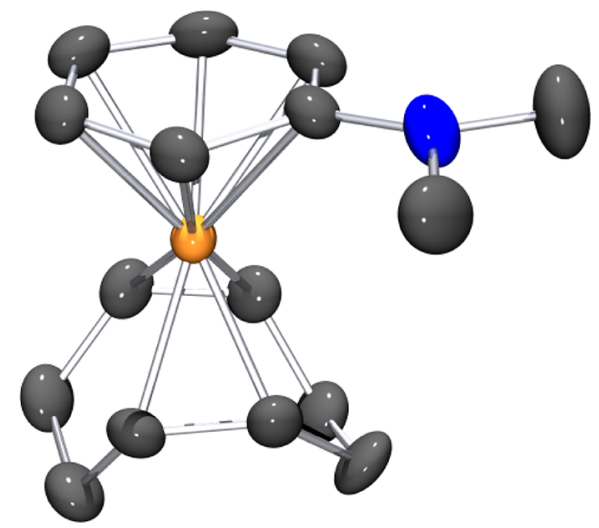

(B)

(C)
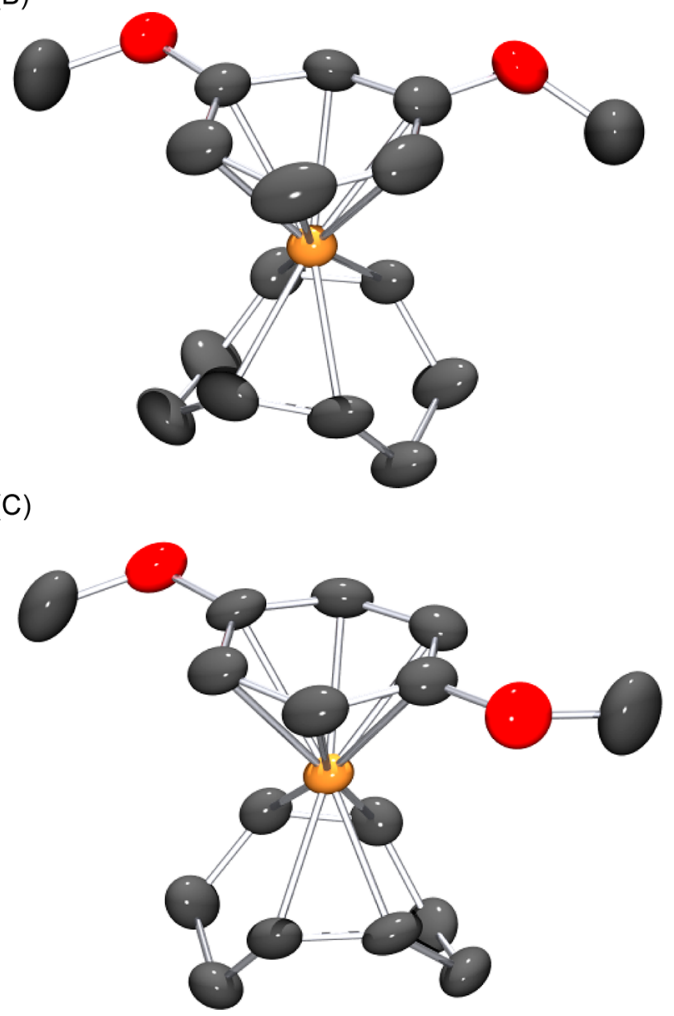

Figure 2. Molecular structures by single-crystal X-ray diffration for 1d (A), $1 \mathrm{~g}$ (B), and $\mathbf{1 h}(\mathrm{C})$. All hydrogen atoms are omitted for clarity. Ellipsoids represent $50 \%$ probability.

In addition to the naphthalene complex, several of the $\left[\mathrm{Ru}\left(\eta^{6}\right.\right.$ arene $\left.)\left(\eta^{4}-1,5-\mathrm{COD}\right)\right]$ compounds containing electron-donating substituents catalyzed the formation of cross-dimers in moderate to high yield (entries 1-5). The acetophenone complex 1e was completely inactive (entry 6), probably because the electron-withdrawing COMe substituent stabilizes $\eta^{6}$ coordination, thus disfavoring arene dissociation. It is worth noting that the 1,3-dimethoxybenzene complex $1 \mathrm{~g}$ produced cross-dimers in $74 \%$ yield after $14 \mathrm{~h}$ at $50{ }^{\circ} \mathrm{C}$ (entry 9 ), whereas the 1,2- and 1,4-analogues (1f,h) were much less active under similar conditions; the reasons for this difference remain unclear. As noted above, the $\mathrm{N}, \mathrm{N}$-dimethylaniline complex $1 \mathrm{~d}$ contains one remarkably long $\mathrm{Ru}-\mathrm{C}$ (arene) bond, indicating that the arene in this case might be fairly weakly bound, but $\mathbf{1 d}$ is nevertheless not the most active catalyst. Finally, we note that the isomeric ratio $\mathbf{4 a} / \mathbf{4 b}$ of the cross-dimers catalyzed by the anisole complex $\mathbf{1 c}$ at $100{ }^{\circ} \mathrm{C}$ for $4 \mathrm{~h}$ is strongly in favor of $\mathbf{4 b}$ 
Table 7. Distortions of the Aromatic Fragment in 1d,f.g and Selected Bond Distances between Ruthenium and the Aromatic Carbons (Å)

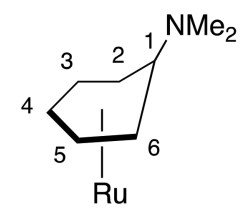

1d

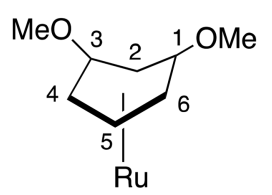

19

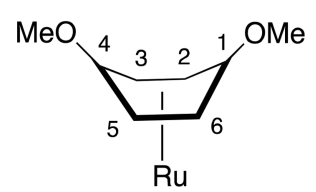

$1 \mathrm{~h}$

\begin{tabular}{cccc} 
& $\mathbf{1 d}$ & $\mathbf{1 g}$ & $\mathbf{1 h}$ \\
$\mathrm{Ru}-\mathrm{C}(1)$ & $2.385(3)$ & $2.279(4)$ & $2.297(4)$ \\
$\mathrm{Ru}-\mathrm{C}(2)$ & $2.210(3)$ & $2.200(4)$ & $2.185(4)$ \\
$\mathrm{Ru}-\mathrm{C}(3)$ & $2.264(3)$ & $2.304(6)$ & $2.258(4)$ \\
$\mathrm{Ru}-\mathrm{C}(4)$ & $2.284(4)$ & $2.279(5)$ & $2.310(4)$ \\
$\mathrm{Ru}-\mathrm{C}(5)$ & $2.204(3)$ & $2.189(4)$ & $2.205(4)$ \\
$\mathrm{Ru}-\mathrm{C}(6)$ & $2.275(3)$ & $2.274(4)$ & $2.259(4)$ \\
\hline
\end{tabular}

Table 8. Cross-Dimerization of 2,3-Dimethylbutadiene with Methyl Acrylate Catalyzed by $\left[\operatorname{Ru}\left(\eta^{6}\right.\right.$-arene $\left.)\left(\eta^{4}-1,5-C O D\right)\right]$ (1) ${ }^{a}$

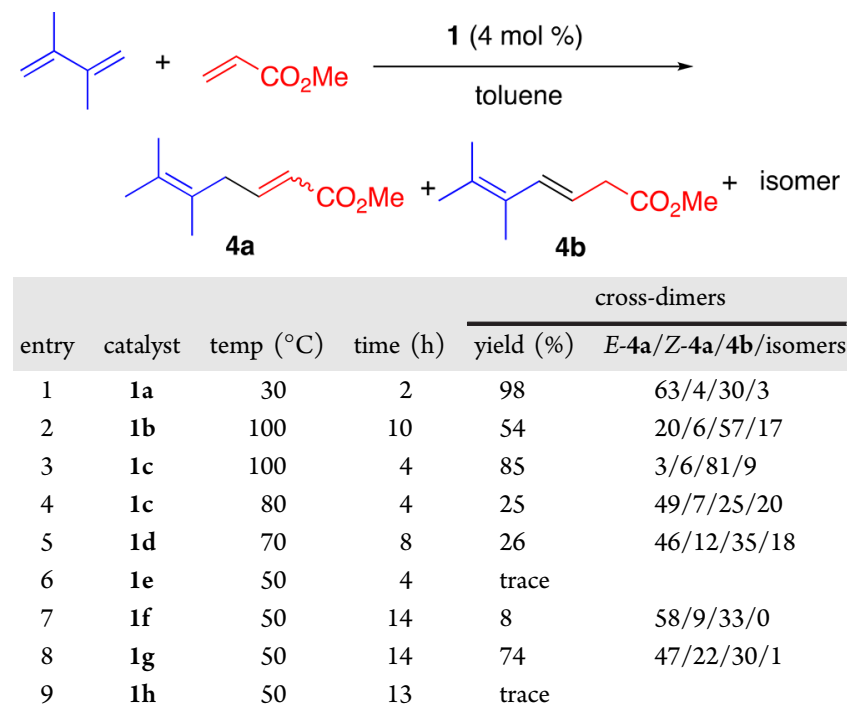

${ }^{a}$ Conditions: 1 (0.029-0.030 mmol), 2,3-dimethylbutadiene (0.89 $\mathrm{mmol})$, methyl acrylate $(0.70 \mathrm{mmol})$. Yields and product ratios were determined by GLC.

(entry 3), in marked contrast with the results reported in Table 5. This apparent reversal in regioselectivity is probably caused by thermal, $\mathbf{R u}$-catalyzed isomerization of initially formed $\mathbf{4 a}$ as the kinetic product of the coupling. In agreement, the isomeric ratio of the cross-dimerization product after $4 \mathrm{~h}$ at $80^{\circ} \mathrm{C}$ using 1c as catalyst favors $\mathbf{4 a}$ over $\mathbf{4 b}$. The occurrence of the isomerization of cross-dimer $\mathbf{3} \mathbf{a}$ to $\mathbf{3} \mathbf{b}$ has been demonstrated. ${ }^{20 a}$

Synthesis of $\left[\mathrm{RuCl}_{2}\left(\eta^{6} \text {-anisole }\right)\right]_{2}(5 \mathrm{c})$. These promising results with cross-dimerization using the $\mathrm{Ru}\left(\eta^{4}-1,5-\mathrm{COD}\right)$ complexes of anisole (1c) and 1,3-dimethoxybenzene (1g) as catalysts prompted us to examine the $\mathrm{Ru}^{\mathrm{II}} \mathrm{Cl}_{2}$ complexes of these aromatics, $\mathbf{5 c , g}$, respectively, as possible precursors. A product formulated as $\left[\mathrm{RuCl}_{2}\left(\eta^{6} \text {-anisole }\right)\right]_{2}$ (5c) was first reported briefly by Bennett and Smith in 1974 as a brown solid, obtained from the reaction of hydrated $\mathrm{RuCl}_{3}$ with 1methoxycyclohexa-1,4-diene, the Birch reduction product of anisole, in refluxing methanol in $25 \%$ yield. ${ }^{31}$ The formulation was based on elemental analysis and ${ }^{1} \mathrm{H}$ NMR data, though it was noted that the product contained about $10 \%$ of the benzene complex $\left[\mathrm{RuCl}_{2}\left(\eta^{6} \text {-benzene }\right)\right]_{2}(\mathbf{5 b})$, arising from competing demethoxylation of anisole. Soleimannejad and White also re-examined and reported on this chemistry. ${ }^{32} \mathrm{We}$ attempted to prepare $5 \mathrm{c}$ from methanolic $\mathrm{RuCl}_{3}$ and 1methoxycyclohexa-1,4-diene (Scheme 2: method A). The

Scheme 2
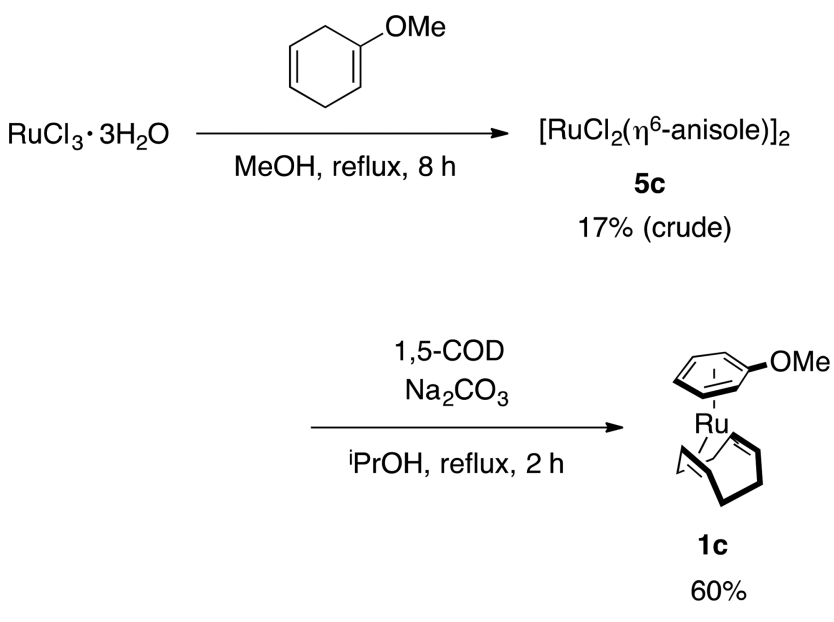

initially formed, poorly soluble green-brown solid was Soxhlet-extracted with hot chloroform to give a brown solution, from which a green-brown solid was obtained after evaporation of the solvent. The ${ }^{1} \mathrm{H}$ NMR spectrum in DMSO- $d_{6}$ indicated it to be a mixture of the anisole complex 5c (89\%) and the benzene complex $\mathbf{5 b}(11 \%)$, but the estimated yield remained generally in the range of only $10-17 \%$. Note that Iwata and Ogata $^{33}$ reported that these compounds also contain $\left[\mathrm{RuCl}_{2}\left(\eta^{6} \text {-arene }\right)\right]_{n}\left[\mathrm{RuCl}_{2}\right]_{m} \quad(m / n=0.1-0.2$ for arene $=$ benzene; $m / n=0.4-0.5$ for arene = mesitylene; $m / n=1-2$ for arene $=1,3,5$-triphenylbenzene), rather than the previously assumed $\left[\mathrm{RuCl}_{2}\left(\eta^{6} \text {-arene }\right)\right]_{2}$. Our elemental analyses are fairly consistent with the empirical formula $\left[\mathrm{RuCl}_{2}\left(\eta^{6}\right.\right.$-anisole $\left.)\right]$ $\left[\mathrm{RuCl}_{2}\right]_{0.22}$, and the chemical reactions of this product with $\mathrm{PMe}_{3}$ are also consistent with this composition (see the Supporting Information).

Following the procedure of Vitulli et al., ${ }^{29}$ we prepared an analytically pure sample of $\mathbf{5 c}$ as an orange powder in $83 \%$ yield based on $\mathrm{Ru}$ by treatment of $\left[\mathrm{Ru}\left(\eta^{6}\right.\right.$-anisole $\left.)\left(\eta^{4}-1,5-\mathrm{COD}\right)\right]$ with hydrochloric acid (method B). Except for the absence of peaks due to $\mathbf{5 b}$, the ${ }^{1} \mathrm{H}$ NMR spectrum of this solid in DMSO$d_{6}$ was identical with that of the green-brown solid made by method A.

Similar attempts to prepare $\left[\mathrm{RuCl}_{2}\left(\eta^{6}\right.\right.$-1,3-dimethoxybenzene $)]_{2}$ (5f) by heating 1,3-dimethoxy-1,4-cyclohexadiene with methanolic $\mathrm{RuCl}_{3}$ at $50{ }^{\circ} \mathrm{C}$ for 2 days failed, the only product isolated being 3-methoxy-2-cyclohexenone.

Catalytic Cross-Dimerization by $\left[\mathrm{RuCl}_{2}\left(\eta^{6} \text {-anisole }\right)\right]_{2}$ (5c) as the Catalyst Precursor. Using 5c with a reductant and 1,5-COD, a catalytic cross-dimerization between 2,3dimethylbutadiene with styrene was performed (Table 9).

In a typical experiment, a suspension of $5 \mathrm{c}(5 \mathrm{~mol} \%), 1,5-$ COD $(20 \mathrm{~mol} \%)$, and $\mathrm{Na}_{2} \mathrm{CO}_{3}(20 \mathrm{~mol} \%)$ was heated in a Schlenk tube in ${ }^{\mathrm{i}} \mathrm{PrOH}$ at $100{ }^{\circ} \mathrm{C}$ for $1 \mathrm{~h}$, and after the reaction mixture was cooled to room temperature, 2,3-dimethylbutadiene and styrene were added. After $6 \mathrm{~h}$ at $100{ }^{\circ} \mathrm{C}$, the crossdimers were obtained in $8 \%$ yield (Table 9 , entry 1 ). The 
Table 9. Catalytic Cross-Dimerization between 2,3Dimethylbutadiene with Styrene Catalyzed by $\left[\mathrm{RuCl}_{2}\left(\eta^{6}-\right.\right.$ anisole) $]_{2}(5 \mathrm{c})$ with $1,5-\mathrm{COD}$ in the Presence of $\mathrm{Na}_{2} \mathrm{CO}_{3}{ }^{a}$

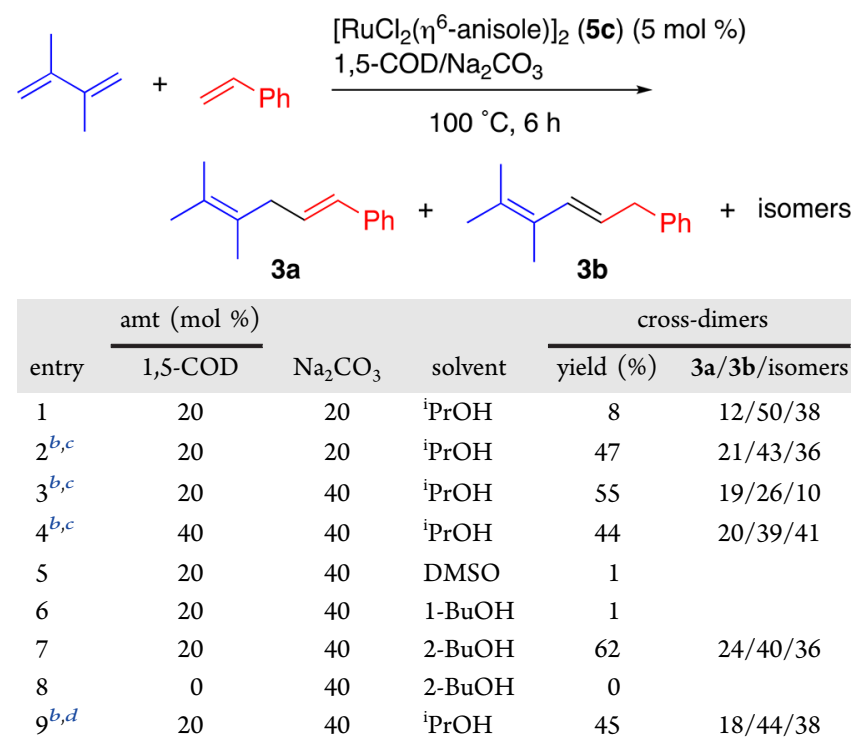

${ }^{a}$ In all reactions, 2,3-dimethylbutadiene and styrene were added after pretreatment of $5 \mathrm{c}$ with $1,5-\mathrm{COD}$ and $\mathrm{Na}_{2} \mathrm{CO}_{3}$ at $100{ }^{\circ} \mathrm{C}$ (oil bath temperature) for $1 \mathrm{~h}$ : 2,3-dimethylbutadiene $(0.88 \mathrm{mmol})$, styrene $(0.75 \mathrm{mmol}) .{ }^{b}$ This reaction was carried out in an autoclave. ${ }^{{ }^{c}}$ Time 10 h. ${ }^{d}\left[\mathrm{Ru}(\mathrm{OAc})_{2}\left(\eta^{6}\right.\right.$-anisole)] (prepared by treatment of $5 \mathrm{c}$ with an excess of $\mathrm{AgOAc}$ ) was used for the catalyst precursor.

reaction in an autoclave improved the product yield (47\% yield), probably by preventing the loss of 2,3-dimethylbutadiene. When the relative amount of $\mathrm{Na}_{2} \mathrm{CO}_{3}$ was increased to $40 \mathrm{~mol} \%$, there was a small increase in the yield of the crossdimers (55\% yield). With 2-butanol, the product yield increased to $62 \%$ but the reaction using 1-butanol significantly decreased the product yield (entries 6 and 7). The high efficiency of secondary alcohols suggests that the reduction of $5 \mathbf{c}$ occurs via $\beta$-hydride elimination from an alkoxoruthenium species. The cross-dimerization did not occur in the absence of 1,5-COD (entry 8).

\section{CONCLUDING REMARKS}

We have shown that a catalytically active species for the onepot $\mathrm{C}-\mathrm{C}$ coupling between 2,3-dimethylbutadiene and styrene or methyl acrylate can be generated in situ by reduction of $\left[\mathrm{Ru}(\mathrm{acac})_{2}\left(\eta^{4}\right.\right.$-cyclic diene $\left.)\right](2)$ with $\mathrm{BuLi}$ or of $\left[\mathrm{RuCl}_{2}\left(\eta^{6}\right.\right.$ arene)] (5)/1,5-COD with $\mathrm{Na}_{2} \mathrm{CO}_{3}$. With these procedures, it is not necessary to isolate the air-sensitive $\mathrm{Ru}(0)$ species which is the actual catalyst precursor. This is a clear advantage over the corresponding $\mathrm{Ru}(0)$ naphthalene system $1 \mathrm{a}$, although the latter is probably catalytically more active. Moreover, the present methods could generate a catalytically active $\mathrm{Ru}(0)$ species, even if $\left[\mathrm{Ru}\left(\eta^{6}\right.\right.$-naphthalene $\left.) \mathrm{L}\right]$ cannot survive during the reduction using sodium naphthalene. Of the two present procedures starting from $\mathrm{Ru}(\mathrm{II})$ complexes, in situ reduction of $\left[\mathrm{Ru}(\mathrm{acac})_{2} \mathrm{~L}\right]$ with 2 equiv of BuLi is probably the more facile, reliable, and practical protocol for generating an active $\mathrm{Ru}(0)$ species that is capable of catalyzing the cross-dimerization of conjugated dienes and substituted alkenes. With this amount, $\mathrm{BuLi}$ probably cannot reduce the $\mathrm{Ru}(\mathrm{II})$ species completely. However, further addition of BuLi causes undesirable polymerization of substrates. This is probably why the present system is catalytically less active than 1a. However, presumably one needs only a minor amount of a $\mathrm{Ru}(0)$ species for the catalysis to be effective. Controls of the regioselective formation of the $\mathrm{C}=\mathrm{C}$ bond and enantioselective cross-dimerizations remain the challenges in the future for the preparative-scale catalysis.

\section{EXPERIMENTAL SECTION}

General Procedures. All manipulations and reactions were performed under dry nitrogen with use of standard Schlenk and vacuum line techniques. Diethyl ether, THF, benzene, toluene, and hexane were dried and deoxygenated with a Glass Contour Ultimate Solvent System. The following starting materials were prepared according to literature methods: Rieke $\mathrm{Mg}^{13}$ and Rieke $\mathrm{Zn},{ }^{22}$ $\left[\mathrm{Ru}(\mathrm{acac})_{3}\right],{ }^{34}\left[\mathrm{Ru}\left(\eta^{4}-1,5-\mathrm{COD}\right)\left(\eta^{6}-1,3,5-\mathrm{COT}\right)\right],{ }^{35}\left[\mathrm{Ru}(\mathrm{acac})_{2}\left(\eta^{4}-\right.\right.$ $1,5-\mathrm{COD})],{ }^{36}\left[\mathrm{Ru}\left(\eta^{6}\right.\right.$-naphthalene $\left.)\left(\eta^{4}-1,5-\mathrm{COD}\right)\right](\mathbf{1 a}),{ }^{24}$ and $[\mathrm{Ru}-$ $\left(\eta^{6}\right.$-benzene $\left.)\left(\eta^{4}-1,5-\mathrm{COD}\right)\right](\mathbf{1 b}) .{ }^{26}$ The known complexes $\left[\operatorname{Ru}\left(\eta^{6}\right.\right.$ arene $)\left(\eta^{4}-1,5\right.$-COD) $]$ (arene $=$ anisole, acetophenone $)^{29}$ were made from 1a and the arene in the presence of acetonitrile by use of the literature procedure. ${ }^{24}\left[\mathrm{RuCl}_{2}\left(\eta^{6}\right.\right.$-anisole $\left.)\right](\mathbf{5 c})$ was also prepared by the literature method. ${ }^{31}$ 2-Phenylbicyclo[3.3.1]nona-2,6-diene was prepared according to the modification of the reported procedure. ${ }^{19 \mathrm{~b}}$ Solutions of $\mathrm{BuLi}(1.003 \mathrm{M})$ were standardized by titration with 1,10 phenanthroline/sec- $\mathrm{BuOH}(1.003 \mathrm{M})$ prior to use. 2,5-Dimethyl-7,8(tetrafluorobenzo)bicyclo[2.2.2] octatriene e $^{37}$ and (3,5-dioxa-4phosphacyclohepta[2,1-a:3,4-a'] dinaphthalen-4-yl)iminostilbene ${ }^{38}$ were prepared by literature methods. dcype was prepared according to literature methods. ${ }^{39}$ All other reagents were obtained from commercial suppliers and used as received. Chromatographic separation was carried out on $\mathrm{Al}_{2} \mathrm{O}_{3}$ (Merck, Activity I, 250 mesh). ${ }^{1} \mathrm{H},{ }^{13} \mathrm{C}$, and ${ }^{31} \mathrm{P}\left\{{ }^{1} \mathrm{H}\right\}$ NMR spectra were recorded on JEOL ECX400P (400 MHz for $\left.{ }^{1} \mathrm{H}\right)$ and JEOL Lambda-300 (300 MHz for $\left.{ }^{1} \mathrm{H}\right)$ instruments. Benzene- $d_{6}$ was distilled over sodium wire and stored under vacuum. Chemical shifts $(\delta)$ are given in $\mathrm{ppm}$, relative to internal TMS for ${ }^{1} \mathrm{H}$ and ${ }^{13} \mathrm{C}$. All coupling constants are given in $\mathrm{Hz}$. Most elemental analyses were carried out on a PerkinElmer 2400 series II CHN analyzer; some $\mathrm{C}, \mathrm{H}, \mathrm{Cl}$ analyses on $\mathbf{5 c}$ were done at the Center for Organic Elemental Microanalysis, Department of Pharmaceutical Sciences, Kyoto University, and at the Campbell Microanalytical Laboratory, the University of Otago, Otago, New Zealand. IR spectra were recorded on a JASCO FT/IR-4100 instrument with use of $\mathrm{KBr}$ disks. GLC analysis was performed on a Shimadzu GC-14B instrument with a FID detector equipped with a ZB-WAX plus column $(0.25 \mathrm{~mm}$ i.d. $\times 30 \mathrm{~m})$. The GC-MS analyses were performed on a Shimadzu QP2010 instrument.

Preparations of $\left[\mathrm{Ru}(\mathrm{acac})_{2}\right.$ (2-phenylbicyclo[3.3.1]nona-2,6diene)] (2b). Complex $2 \mathbf{b}$ was prepared according to our previous report $^{21 \mathrm{c}}$ using $\left[\mathrm{Ru}(\mathrm{acac})_{3}\right](1.5427 \mathrm{~g}, 3.8723 \mathrm{mmol})$ with 2phenylbicyclo[3.3.1]nona-2,6-diene $(795.6 \mathrm{mg}, 4.053 \mathrm{mmol})$ and $\mathrm{Zn}$ dust $(2.5 \mathrm{~g}, 39 \mathrm{mmol})$ in THF $(39 \mathrm{~mL})$ and water $(1 \mathrm{~mL})$. Crystallization of the resulting oil from cold $\left(-20^{\circ} \mathrm{C}\right)$ hexane $(10$ $\mathrm{mL}$ ) gave orange plates of $\mathbf{2 b}$ (57\% yield, $1.0916 \mathrm{~g}, 2.2027 \mathrm{mmol}$, rac$\Delta-(S, S)-\mathbf{2 b} / \mathrm{rac}-\Lambda-(S, S)-\mathbf{2 b}=62 / 38)$. From the mother liquor, $\mathbf{2 b}$ was obtained (24\% yield, $488.0 \mathrm{mg}, 0.9847 \mathrm{mmol}, \mathrm{rac}-\Delta-(S, S)-2 \mathbf{b} / \mathrm{rac}-\Lambda$ $(S, S)-\mathbf{2 b}=93 / 7)$. Data for rac- $\Delta-(S, S)-\mathbf{2 b}$ are as follows. ${ }^{1} \mathrm{H}$ NMR $\left(400 \mathrm{MHz}, \mathrm{CDCl}_{3}\right): \delta 1.58$ (br s, $\left.2 \mathrm{H}, \mathrm{CH}_{2}\right), 1.73(\mathrm{~s}, 3 \mathrm{H}, \mathrm{Me}), 1.81(\mathrm{~s}$, $3 \mathrm{H}, \mathrm{Me}), 1.85(\mathrm{~s}, 3 \mathrm{H}, \mathrm{Me}), 2.15(\mathrm{~s}, 3 \mathrm{H}, \mathrm{Me}), 2.3-2.6\left(\mathrm{~m}, 5 \mathrm{H}, \mathrm{CH}_{2}\right.$ and $\mathrm{CH}), 2.65$ (br s, 1H, bridge head), $4.09\left(\mathrm{dd},{ }^{3} \mathrm{~J}_{\mathrm{H}-\mathrm{H}}=7.8,5.2 \mathrm{~Hz}, 1 \mathrm{H}\right.$, $=\mathrm{CH}), 4.32\left(\mathrm{dd},{ }^{3} \mathrm{~J}_{\mathrm{H}-\mathrm{H}}=7.8,4.0 \mathrm{~Hz}, 1 \mathrm{H},=\mathrm{CH}\right), 5.16\left(\mathrm{~d},{ }^{3} J_{\mathrm{H}-\mathrm{H}}=\right.$ $2.9 \mathrm{~Hz}, 1 \mathrm{H},=\mathrm{CH}), 5.29(\mathrm{~s}, 1 \mathrm{H}, \mathrm{CH}$ in acac), $5.38(\mathrm{~s}, 1 \mathrm{H}, \mathrm{CH}$ in acac), 7.04-7.16 (m, 5H,Ph). ${ }^{13} \mathrm{C}\left\{{ }^{1} \mathrm{H}\right\} \mathrm{NMR}\left(100.5 \mathrm{MHz}, \mathrm{CDCl}_{3}\right): \delta$ 27.03, 27.29, 28.30, 28.39, 29.51, 34.37, 35.62, 38.59, 38.94, 78.17, 86.32, 92.49, 93.15, 98.37, 98.82, 125.57, 126.21 (2C), 126.25 (2C), 143.54, 184.37, $186.15(2 \mathrm{C}), 186.25 . \mathrm{IR}\left(\mathrm{KBr}, \mathrm{cm}^{-1}\right): 3086(\mathrm{w}), 3016$ (w), $2966(\mathrm{w}), 2910(\mathrm{~m}), 2836(\mathrm{~m}), 1576$ (vs), 1519 (vs), 1401 (vs), $1271(\mathrm{~m}), 1196(\mathrm{~m}), 1184(\mathrm{~m}), 1017(\mathrm{~s}), 933(\mathrm{~m}), 764(\mathrm{~s}), 691(\mathrm{~m})$, $611(\mathrm{~m}), 436(\mathrm{~m})$. Anal. Calcd for $\mathrm{C}_{25} \mathrm{H}_{30} \mathrm{O}_{4} \mathrm{Ru}: \mathrm{C}, 60.59 ; \mathrm{H}, 6.10$. Found: 60.57 ; H, 5.98. Data for $\operatorname{rac}-\Lambda-(S, S)-2 b$ are as follows. ${ }^{1} \mathrm{H}$ NMR $\left(400 \mathrm{MHz}, \mathrm{CDCl}_{3}\right): \delta 1.63(\mathrm{~s}, 3 \mathrm{H}, \mathrm{Me}), 1.65$ (br s, overlapped, $2 \mathrm{H}, \mathrm{CH}_{2}$ ), 1.81 (s, 3H, Me), 1.82 (s, 3H, Me), 2.13 (s, 3H, Me), 2.3- 
$2.5\left(\mathrm{~m}, 3 \mathrm{H}, \mathrm{CH}_{2}\right.$ and $\left.\mathrm{CH}\right), 2.65$ (br s, $1 \mathrm{H}$, bridge head), $3.18(\mathrm{dt}$, $\left.{ }^{3} J_{\mathrm{H}-\mathrm{H}}=14.3,4.0 \mathrm{~Hz}, 1 \mathrm{H}, \mathrm{CH}_{2}\right), 3.23\left(\mathrm{dt},{ }^{3} J_{\mathrm{H}-\mathrm{H}}=14.3,4.0 \mathrm{~Hz}, 1 \mathrm{H}\right.$, $\left.\mathrm{CH}_{2}\right), 3.65\left(\mathrm{dd},{ }^{3} J_{\mathrm{H}-\mathrm{H}}=8.3,5.2 \mathrm{~Hz}, 1 \mathrm{H},=\mathrm{CH}_{2}\right), 4.30\left(\mathrm{dd},{ }^{3} J_{\mathrm{H}-\mathrm{H}}=\right.$ $\left.8.3,4.3 \mathrm{~Hz}, 1 \mathrm{H},=\mathrm{CH}_{2}\right), 4.47(\mathrm{~s}, 1 \mathrm{H}, \mathrm{CH}$ in acac), $5.15(\mathrm{~s}, 1 \mathrm{H}, \mathrm{CH}$ in acac), $5.39\left(\mathrm{~d},{ }^{3} J_{\mathrm{H}-\mathrm{H}}=4.0 \mathrm{~Hz}, 1 \mathrm{H},=\mathrm{CH}\right), 6.97-7.02(\mathrm{~m}, 3 \mathrm{H}, P h)$, 7.04-7.16 (m, 2H,Ph). ${ }^{13} \mathrm{C}\left\{{ }^{1} \mathrm{H}\right\}$ NMR (100.5 MHz, $\left.\mathrm{CDCl}_{3}\right): \delta 26.89$ (s), 26.97 (s), 28.40 (s), 28.88 (s), 29.72 (s), 35.06 (s), 25.81 (s), $37.10(\mathrm{~s}), 37.40(\mathrm{~s}), 81.90(\mathrm{~s}), 85.53(\mathrm{~s}), 89.29(\mathrm{~s}), 91.66(\mathrm{~s}), 97.61$ (s), 98.19 (s), 125.31 (s, 2C), 125.53 (s), 126.74 (s, 2C), 143.08 (s), 185.07 (s), 185.32 (s), 185.81 (s), 186.79 (s).

$\left[\mathrm{Ru}(\mathrm{acac})_{2}\right.$ (2,5-dimethyl-7,8-(tetrafluorobenzo)bicyclo[2.2.2]octatriene)] (2c). 2c was prepared from $\left[\mathrm{Ru}(\mathrm{acac})_{3}\right]$ (410.4 $\mathrm{mg}, 1.030 \mathrm{mmol}$ ) with 2,5-dimethyl-7,8-(tetrafluorobenzo)bicyclo[2.2.2] octatriene $(275.8 \mathrm{mg}, 1.085 \mathrm{mmol})$ and $\mathrm{Zn}$ dust $(0.7$ g, $11 \mathrm{mmol}$ ) (79\% yield, $448.0 \mathrm{mg}, 0.8094 \mathrm{mmol}, \mathrm{rac}-\Delta-(S, S)-2 \mathrm{c} / \mathrm{rac}-$ $\Lambda-(S, S)-\mathbf{2 c}=85 / 15)$. Data for rac- $\Delta-(S, S)-2 \mathrm{c}$ are as follows. ${ }^{1} \mathrm{H}$ NMR $\left(400 \mathrm{MHz}, \mathrm{CDCl}_{3}\right): \delta 1.48(\mathrm{~s}, 6 \mathrm{H}, \mathrm{Me}), 1.86(\mathrm{~s}, 6 \mathrm{H}, \mathrm{Me}$ in acac), 2.25 (s, $6 \mathrm{H}, M e$ in acac), $3.69\left(\mathrm{~d},{ }^{3} J_{\mathrm{H}-\mathrm{H}}=6.3 \mathrm{~Hz}, 2 \mathrm{H},=\mathrm{CH}\right), 4.79(\mathrm{~d}$, ${ }^{3} \mathrm{~J}_{\mathrm{H}-\mathrm{H}}=6.3 \mathrm{~Hz}, 2 \mathrm{H}, \mathrm{CH}$ in bridge head), 5.35 (s, $2 \mathrm{H}, \mathrm{CH}$ in acac). ${ }^{13} \mathrm{C}\left\{{ }^{1} \mathrm{H}\right\}$ NMR (100.5 MHz, $\left.\mathrm{CDCl}_{3}\right): \delta 17.47(\mathrm{Me}), 27.14(\mathrm{Me}$ in acac), 28.36 ( $M e$ in acac), 47.51 (bridge head), $69.24(=\mathrm{CH}), 84.13$ (=C<), 99.30 (acac), 127.1-127.4 (m, aromatic), 186.57 (CO), 187.10 (CO). IR (KBr, cm $\left.{ }^{-1}\right): 2975$ (w), 2896 (m), 1594 (vs), 1580 (vs), 1519 (vs), 1489 (vs), 1368 (m), 1297 (s), 1269 (s), 1200 (m), 1175 (m), 1135 (m), $1106(\mathrm{~m}), 1085(\mathrm{~m}), 1024(\mathrm{~s}), 998(\mathrm{~m}), 930(\mathrm{~s})$, $772(\mathrm{~s}), 699(\mathrm{w}), 617(\mathrm{~m}), 437(\mathrm{~m})$. Anal. Calcd for $\mathrm{C}_{24} \mathrm{H}_{24} \mathrm{~F}_{4} \mathrm{O}_{4} \mathrm{Ru}$ : C, 52.08; H, 4.37. Found: C, 51.81; H, 4.54. Data for $\mathrm{rac}^{-\Lambda}-(S, S)-2 \mathrm{c}$ are as follows. ${ }^{1} \mathrm{H}$ NMR $\left(400 \mathrm{MHz}, \mathrm{CDCl}_{3}\right): \delta 1.21(\mathrm{~s}, 6 \mathrm{H}, \mathrm{Me}), 1.88$ $\left(\mathrm{s}, 6 \mathrm{H}, M e\right.$ in acac), $2.28\left(\mathrm{~s}, 6 \mathrm{H}, M e\right.$ in acac), $4.13\left(\mathrm{~d},{ }^{3} J_{\mathrm{H}-\mathrm{H}}=5.2 \mathrm{~Hz}\right.$, $2 \mathrm{H},=\mathrm{CH}), 4.97\left(\mathrm{~d},{ }^{3} \mathrm{~J}_{\mathrm{H}-\mathrm{H}}=5.2 \mathrm{~Hz}, \mathrm{CH}\right.$ in bridge head $), 5.34(\mathrm{~s}, 2 \mathrm{H}$, $\mathrm{CH}$ in acac). ${ }^{13} \mathrm{C}\left\{{ }^{1} \mathrm{H}\right\}$ NMR (100.5 MHz, $\left.\mathrm{CDCl}_{3}\right): \delta 18.35$ (s, Me), 27.18 (s, Me in acac), 28.30 (s, Me in acac), 47.39 (s, bridge head), $71.59(\mathrm{~s},=\mathrm{CH}), 85.18(\mathrm{~s},=\mathrm{CH}), 98.74(\mathrm{~s}, \mathrm{CH}$ in acac $), 127.1-127.4$ (m, aromatic), 186.40 (s, CO), 187.41 (s, CO).

[Ru(acac) ${ }_{2}$ (3,5-dioxa-4-phosphacyclohepta[2,1-a:3,4- $\left.a^{\prime}\right]$ dinaphthalen-4-yl)iminostilbene] (2d). 2d was prepared from $\left[\mathrm{Ru}(\mathrm{acac})_{3}\right] \quad(651.5 \mathrm{mg}, \quad 1.635 \mathrm{mmol})$ with (3,5-dioxa-4phosphacyclohepta $\left[2,1-a: 3,4-a^{\prime}\right]$ dinaphthalene-4-yl)iminostilbene (870.3 $\mathrm{mg}, 1.715 \mathrm{mmol})$ and $\mathrm{Zn}$ dust $(1.0 \mathrm{~g}, 15 \mathrm{mmol})$ as an analytically pure pale yellow powder ( $88 \%$ yield, $1.3208 \mathrm{~g}$, 1.5028 mmol, rac- $\Delta-(S)-\mathbf{2 d} / \mathrm{rac}-\Lambda-(S)-\mathbf{2 d}=79 / 21)$. Data for $\mathrm{rac}-\Delta-(S)-\mathbf{2 d}$ are as follows. ${ }^{1} \mathrm{H}$ NMR $\left(400 \mathrm{MHz}, \mathrm{CDCl}_{3}\right): \delta 0.60(\mathrm{~s}, 3 \mathrm{H}, \mathrm{Me}), 1.59$ $(\mathrm{s}, 3 \mathrm{H}, \mathrm{Me}), 2.04(\mathrm{~s}, 3 \mathrm{H}, \mathrm{Me}), 2.08(\mathrm{~s}, 3 \mathrm{H}, \mathrm{Me}), 4.67(\mathrm{~s}, 1 \mathrm{H}, \mathrm{CH}$ in acac), $4.90\left(\mathrm{~d},{ }^{3} J_{\mathrm{H}-\mathrm{H}}=10.0 \mathrm{~Hz}, 1 \mathrm{H},=\mathrm{CH}\right), 5.33\left(\mathrm{~d},{ }^{3} J_{\mathrm{H}-\mathrm{H}}=10.0 \mathrm{~Hz}\right.$, $1 \mathrm{H},=\mathrm{CH}), 5.46(\mathrm{~s}, 1 \mathrm{H}, \mathrm{CH}$ in acac $), 7.01\left(\mathrm{~d},{ }^{3} J_{\mathrm{H}-\mathrm{H}}=8.6 \mathrm{~Hz}, 1 \mathrm{H}\right.$, aromatic), $7.1-7.2(\mathrm{~m}, 5 \mathrm{H}$, aromatic), $7.2-7.25(\mathrm{~m}, 2 \mathrm{H}$, aromatic), $7.3-7.35(\mathrm{~m}, 3 \mathrm{H}$, aromatic $), 7.4(\mathrm{~m}, 2 \mathrm{H}$, aromatic $), 7.43(\mathrm{~m}, 1 \mathrm{H}$, aromatic), $7.58\left(\mathrm{~d},{ }^{3} J_{\mathrm{H}-\mathrm{H}}=9.2 \mathrm{~Hz}, 1 \mathrm{H}\right.$, aromatic $), 7.62\left(\mathrm{~d},{ }^{3} J_{\mathrm{H}-\mathrm{H}}=7.5\right.$ $\mathrm{Hz}, 1 \mathrm{H}$, aromatic), $7.79\left(\mathrm{~d},{ }^{3} J_{\mathrm{H}-\mathrm{H}}=8.6 \mathrm{~Hz}, 2 \mathrm{H}\right.$, aromatic), $7.92(\mathrm{~d}$, ${ }^{3} J_{\mathrm{H}-\mathrm{H}}=8.6 \mathrm{~Hz}, 1 \mathrm{H}$, aromatic), $7.93\left(\mathrm{~d},{ }^{3} J_{\mathrm{H}-\mathrm{H}}=8.0 \mathrm{~Hz}, 1 \mathrm{H}\right.$, aromatic $)$. ${ }^{13} \mathrm{C}\left\{{ }^{1} \mathrm{H}\right\}$ NMR (100 MHz, $\left.\mathrm{CDCl}_{3}\right): \delta 25.30(\mathrm{~s}), 27.68(\mathrm{~s}), 28.53$ (s), $\left(\mathrm{d},{ }^{2} J_{\mathrm{C}-\mathrm{P}}=8.6 \mathrm{~Hz}\right), 28.77(\mathrm{~s}), 80.38(\mathrm{~s}), 83.88$ (s), 98.53 (s), 98.97 $(\mathrm{s}), 121.83(\mathrm{~s}), 122.16(\mathrm{~s}), 122.83(\mathrm{~s}), 124.55(\mathrm{~s}), 124.86(\mathrm{~s}), 125.52$ (s), 125.93 (s), 126.51 (s), 126.70 (s), 126.93 (s), 127.06 (s), 127.43 (s), 127.50 (s), 127.93 (s), 128.15 (s), 129.19 (s), 129.28 (s), 129.43 (s), $129.78(\mathrm{~s}), 130.31(\mathrm{~s}), 131.06(\mathrm{~s}), 131.28(\mathrm{~s}), 131.63(\mathrm{~s}), 132.07$ (s), $132.75(\mathrm{~s}), 141.63(\mathrm{~s}), 131.86(\mathrm{~s}), 141.91(\mathrm{~s}), 142.91\left(\mathrm{~d},{ }^{2} \mathrm{~J}_{\mathrm{C}-\mathrm{P}}=\right.$ $6.7 \mathrm{~Hz}), 142.73\left(\mathrm{~d},{ }^{2} J_{\mathrm{C}-\mathrm{P}}=5.8 \mathrm{~Hz}\right), 147.77(\mathrm{~s}), 149.07(\mathrm{~s}), 185.75(\mathrm{~s})$, $185.87(\mathrm{~s}), 187.41(\mathrm{~s}), 187.46(\mathrm{~s}) .{ }^{31} \mathrm{P}\left\{{ }^{1} \mathrm{H}\right\}$ NMR (162 MHz, $\left.\mathrm{CDCl}_{3}\right)$ : $\delta 192.10$ (s). Data for rac- $\Lambda$ - $(S)-2 \mathrm{~d}$ are as follows. ${ }^{1} \mathrm{H}$ NMR $(400$ $\left.\mathrm{MHz}, \mathrm{CDCl}_{3}\right): \delta 1.14(\mathrm{~s}, 3 \mathrm{H}, \mathrm{Me}), 1.82(\mathrm{~s}, 3 \mathrm{H}, \mathrm{Me}), 1.95(\mathrm{~s}, 3 \mathrm{H}, \mathrm{Me})$, $2.05(\mathrm{~s}, 3 \mathrm{H}, \mathrm{Me}), 5.12\left(\mathrm{~d},{ }^{3} J_{\mathrm{H}-\mathrm{H}}=9.7 \mathrm{~Hz}, 1 \mathrm{H},=\mathrm{CH}\right), 5.28(\mathrm{~s}, 1 \mathrm{H}$, $\mathrm{CH}$ in acac), 5.31 (s, 1H, CH in acac), $5.52\left(\mathrm{~d},{ }^{3} J_{\mathrm{H}-\mathrm{H}}=9.7 \mathrm{~Hz}, 1 \mathrm{H},=\right.$ $\mathrm{CH}), 6.8-7.7\left(\mathrm{~m}\right.$, overlapped, $20 \mathrm{H}$, aromatic). ${ }^{31} \mathrm{P}\left\{{ }^{1} \mathrm{H}\right\}$ NMR $(162$ $\mathrm{MHz}, \mathrm{CDCl}_{3}$ ): $\delta 192.24$ (s). 2d: Anal. Calcd for $\mathrm{C}_{48} \mathrm{H}_{44} \mathrm{NO}_{7} \mathrm{PRu}: \mathrm{C}$, 65.59; H, 5.05; N, 1.59. Found: C, 65.10; H, 4.78; N, 1.54 .

[Ru(acac) ${ }_{2}$ (1,2-bis(dicyclohexylphosphino)ethane)] (2e). Complex $2 \mathrm{e}$ was prepared from $\left[\mathrm{Ru}(\mathrm{acac})_{3}\right](199.6 \mathrm{mg}, 0.5010$ $\mathrm{mmol}$ ) with 1,2-bis(dicyclohexylphosphino)ethane $(222.1 \mathrm{mg}, 0.5255$ $\mathrm{mmol})$ and $\mathrm{Zn}(327.1 \mathrm{mg}, 5.003 \mathrm{mmol})$ in refluxing $\mathrm{THF} / \mathrm{H}_{2} \mathrm{O}$ for 11 $\mathrm{h}$ in $16 \%$ yield. A higher yield of $2 \mathrm{e}$ was obtained as follows: $\left[\mathrm{Ru}\left(\eta^{4}-\right.\right.$ 1,5-COD) $\left.\left(\eta^{6}-1,3,5-\mathrm{COT}\right)\right]$ (546 mg, $\left.1.73 \mathrm{mmol}\right)$ and 1,2-bis(dicyclohexylphosphino)ethane $(756 \mathrm{mg}, 1.80 \mathrm{mmol})$ in benzene $(7$ $\mathrm{mL})$ were treated with acetylacetone $(541 \mu \mathrm{L}, 5.2 \mathrm{mmol})$ at room temperature. After $48 \mathrm{~h}$, the initially orange solution had turned red. After evaporation of all volatile material under reduced pressure, an orange oil remained, which on recrystallization from cold hexane gave analytically pure orange crystals of $2 \mathrm{e}(80 \%$ yield, $1.00 \mathrm{~g}, 1.39 \mathrm{mmol})$. ${ }^{1} \mathrm{H}$ NMR (300 MHz, $\left.\mathrm{C}_{6} \mathrm{D}_{6}\right): \delta 1.14-2.68\left(\mathrm{~m}, 48 \mathrm{H}, \mathrm{PC} y\right.$ and $\left.\mathrm{PC}_{2} \mathrm{H}_{4} \mathrm{P}\right)$, $1.82(\mathrm{~s}, 6 \mathrm{H}, \mathrm{Me}$ in acac), 2.01 (s, 6H, Me in acac), 5.41 (s, $2 \mathrm{H}, \mathrm{CH}$ in acac). ${ }^{31} \mathrm{P}\left\{{ }^{1} \mathrm{H}\right\}$ NMR $\left(121 \mathrm{MHz}, \mathrm{C}_{6} \mathrm{D}_{6}\right): \delta 88.2$ (s). Anal. Calcd for $\mathrm{C}_{36} \mathrm{H}_{62} \mathrm{O}_{4} \mathrm{P}_{2} \mathrm{Ru}$ : C, 59.90; H, 8.66. Found: $\mathrm{C}, 60.21 ; \mathrm{H}, 8.69$.

Catalytic Cross-Dimerization of 2,3-Dimethylbutadiene with Styrene in the Presence of $\left[\operatorname{Ru}(\mathrm{acac})_{2}\left(\eta^{4}-1,5-\mathrm{COD}\right)\right]$ (2a) with/ without Reductant. $\left[\mathrm{Ru}(\mathrm{acac})_{2}\left(\eta^{4}-1,5-\mathrm{COD}\right)\right]$ (2a) (20.63 mg, $0.0506 \mathrm{mmol}$ ) and dibenzyl as an internal standard (36.6 mg, 0.201 mmol) were placed in a $25 \mathrm{~mL}$ Schlenk tube, into which hexane (1.5 $\mathrm{mL})$, styrene (120 $\mu \mathrm{L}, 1.04 \mathrm{mmol}), 2,3$-dimethylbutadiene $(120 \mu \mathrm{L}$, $1.05 \mathrm{mmol}$ ), and $\mathrm{BuLi}(40 \mu \mathrm{L}, 2.33 \mathrm{M}, 0.093 \mathrm{mmol}$ ) were placed from a hypodermic syringe. The reaction mixture was warmed to $50{ }^{\circ} \mathrm{C}$ for $6 \mathrm{~h}$, and the product yields were estimated by GLC (73\% total yield, $3 a / 3 b /$ isomers $=82 / 8 / 10)$. The other evaluations of reductants are summarized in the Supporting Information.

Effect of Amount of BuLi to [Ru(acac) $\left.)_{2}\left(\eta^{4}-1,5-\mathrm{COD}\right)\right]$ (2a) on Cross-Dimerization of 2,3-Dimethylbutadiene with Styrene. Similar to the standard reaction of 2,3-dimethylbutadiene with styrene catalyzed by $\mathbf{2 a} / \mathrm{BuLi}$ described above, the following experiments were performed. 2a (20.49 $\mathrm{mg}, 0.0502 \mathrm{mmol})$, hexane $(1.5 \mathrm{~mL})$, styrene (120 $\mu \mathrm{L}, 1.04 \mathrm{mmol}), 2,3$-dimethylbutadiene $(240 \mu \mathrm{L}, 2.11 \mathrm{mmol})$, $\operatorname{BuLi}(21 \mu \mathrm{L}, 2.3 \mathrm{M}, 0.049 \mathrm{mmol}): 80 \%$ total yield, $3 \mathbf{a} / 3 \mathbf{b} /$ isomers = $84 / 9 / 7$. The other screening data for the amount of $\mathrm{BuLi}$ are summarized in the Supporting Information.

Effect of Diene/Styrene Ratio on [Ru(acac) $\left.)_{2}\left(\eta^{4}-1,5-\mathrm{COD}\right)\right]$ (2a)-Catalyzed Cross-Dimerization of 2,3-Dimethylbutadiene with Styrene. Similar to the standard reaction of 2,3-dimethylbutadiene with styrene catalyzed by $2 \mathrm{a} / \mathrm{BuLi}$ described above, the following experiments were performed. 2a (20.44 mg, 0.0501 $\mathrm{mmol})$, hexane $(1.5 \mathrm{~mL})$, styrene $(340 \mu \mathrm{L}, 2.96 \mathrm{mmol})$, 2,3dimethylbutadiene (120 $\mu \mathrm{L}, 1.05 \mathrm{mmol}), \mathrm{BuLi}(43 \mu \mathrm{L}, 2.3 \mathrm{M}, 0.10$ $\mathrm{mmol}): 81 \%$ total yield, $3 \mathbf{a} / 3 \mathbf{b} /$ isomers $=62 / 31 / 7$. The other screening data for the diene/styrene ratio are summarized in the Supporting Information.

Effect of $\left[\mathrm{Ru}(\mathrm{acac})_{2} \mathrm{~L}\right]$ (2) on Cross-Dimerization of 2,3Dimethylbutadiene with Styrene in the Presence of BuLi. Similar to the standard reaction of 2,3-dimethylbutadiene with styrene catalyzed by $\mathbf{2 a} / \mathrm{BuLi}$ described above, the following experiments were performed. $\left[\mathrm{Ru}(\mathrm{acac})_{2}\right.$ (2-phenylbicyclo[3.3.1]nona-2,6-diene)] (2b) $(24.72 \mathrm{mg}, 0.0498 \mathrm{mmol})$, THF $(1.5 \mathrm{~mL})$, styrene $(115 \mu \mathrm{L}, 1.00$ mmol), 2,3-dimethylbutadiene ( $240 \mu \mathrm{L}, 2.11 \mathrm{mmol}), \mathrm{BuLi}(43 \mu \mathrm{L}, 2.3$ M, $0.10 \mathrm{mmol}$ ): $77 \%$ total yield, $3 \mathbf{a} / 3 \mathbf{b} /$ isomers $=73 / 13 / 14$. The other screening of $\left[\mathrm{Ru}(\mathrm{acac})_{2} \mathrm{~L}\right]$ are summarized in the Supporting Information.

Cross-Dimerization of 2,3-Dimethylbutadiene with Methyl Acrylate. $\left[\mathrm{Ru}(\mathrm{acac})_{2}\left(\eta^{4}-1,5-\mathrm{COD}\right)\right](2 \mathrm{a})(20.66 \mathrm{mg}, 0.0506 \mathrm{mmol})$ and dibenzyl as an internal standard $(35.71 \mathrm{mg}, 0.196 \mathrm{mmol})$ were placed in a $25 \mathrm{~mL}$ Schlenk tube, into which hexane $(1.5 \mathrm{~mL}), 2,3-$ dimethylbutadiene $(120 \mu \mathrm{L}, 1.05 \mathrm{mmol})$, methyl acrylate $(140 \mu \mathrm{L}$, $1.56 \mathrm{mmol})$, and $\mathrm{BuLi}(40 \mu \mathrm{L}, 2.3 \mathrm{M}, 0.093 \mathrm{mmol})$ were placed by a hypodermic syringe. The reaction mixture was warmed to $50{ }^{\circ} \mathrm{C}$ for 6 $\mathrm{h}$, and the product yields were estimated by GLC. The total yield of cross-dimers was $0 \%$. A similar reaction was carried out in THF with 2a (20.33 mg, $0.0498 \mathrm{mmol})$, THF $(1.5 \mathrm{~mL}), \operatorname{BuLi}(40 \mu \mathrm{L}, 0.093$ mmol), 2,3-dimethylbutadiene (120 $\mu \mathrm{L}, 1.05 \mathrm{mmol})$, and methyl acrylate $(140 \mu \mathrm{L}, 1.56 \mathrm{mmol})$, and the product yields were measured by GLC: $65 \%$ total yield, $E-4 a / Z-4 a / 4 b /$ isomers $=67 / 9 / 22 / 2$. The other screenings of the catalysis are summarized in the Supporting Information.

Effect of $\left[\mathrm{Ru}(\mathrm{acac})_{2} \mathrm{~L}\right]$ (2) on Cross-Dimerization of 2,3Dimethylbutadiene with Methyl Acrylate in the Presence of BuLi. Similar to the standard reaction of 2,3-dimethylbutadiene with methyl acrylate catalyzed by $\mathbf{2 a}$ with pretreatment of the catalyst 
precursor with $\mathrm{BuLi}$, the following experiments were performed. $\left[\mathrm{Ru}(\mathrm{acac})_{2}(1,5-\mathrm{COD})\right]$ (2a) (20.63 mg, $\left.0.0506 \mathrm{mmol}\right)$, THF (1.5 $\mathrm{mL}), \mathrm{BuLi}(43 \mu \mathrm{L}, 0.10 \mathrm{mmol}), 2,3$-dimethylbutadiene $(230 \mu \mathrm{L}, 2.02$ $\mathrm{mmol})$, methyl acrylate $(90 \mu \mathrm{L}, 1.00 \mathrm{mmol}): 63 \%$ total yield, $E-4 \mathrm{a} / Z$ $4 \mathbf{a} / \mathbf{4 b} /$ isomers $=81 / 3 / 14 / 2$. The other screening data of the catalyst are summarized in the Supporting Information.

Reaction of $\left[\mathrm{Ru}(\mathrm{acac})_{2}\left(\eta^{4}-1,5-\mathrm{COD}\right)\right]$ (2a) with 2 equiv of BuLi. $\left[\mathrm{Ru}(\mathrm{acac})_{2}\left(\eta^{4}-1,5-\mathrm{COD}\right)\right](2 \mathrm{a})(20.3 \mathrm{mg}, 0.0500 \mathrm{mmol})$ was dissolved in hexane $(1.5 \mathrm{~mL})$, and $\mathrm{BuLi}(2.49 \mathrm{M}, 40.0 \mu \mathrm{L}, 0.996$ $\mathrm{mmol}$ ) was added to the solution under reduced pressure by a hypodermic syringe. Then, methane $\left(99.8 \mu \mathrm{L}, 1019 \mathrm{hPa}, 10^{\circ} \mathrm{C}\right)$ was added to the system as an internal standard. An orange suspension formed immediately. The system was stirred at $0{ }^{\circ} \mathrm{C}$ for $5 \mathrm{~min}$, and the GC analysis (Unicarbon column, $1 \mathrm{~m} \times 3 \mathrm{~mm} \phi$ ) suggests generation of butane (17.6\%), 1-hexene (5.0\%), and (E)-2-butene (1.8\%). (Z)-2Butene was not observed. Then, cyclooctane $(2.0 \mu \mathrm{L}, 0.015 \mathrm{mmol})$ was added to the system as an internal standard. The GLC analysis (OV-1 column, $30 \mathrm{~m} \times 0.25 \mathrm{~mm}$ i.d.) indicated formation of octane (6.9\%).

Reaction of [Ru(acac) $\left.\left(\eta^{4}-1,5-C O D\right)\right](2 a)$ with 2 equiv of BuLi in the Presence of Naphthalene. $\left[\mathrm{Ru}(\mathrm{acac})_{2}\left(\eta^{4}-1,5-\mathrm{COD}\right)\right]$ (2a) $(20.44 \mathrm{mg}, 0.0501 \mathrm{mmol})$ and naphthalene $(12.90 \mathrm{mg}, 0.1008 \mathrm{mmol})$ were dissolved in THF $(1.5 \mathrm{~mL})$, and BuLi $(43 \mu \mathrm{L}, 0.10 \mathrm{mmol})$ was added to the solution. After removal of volatile materials, triphenylmethane $(5.54 \mathrm{mg}, 0.022 \mathrm{mmol})$ was added as an internal standard. 1a: $0.004 \mathrm{mmol}, 8 \%$ yield.

$\left[\mathrm{Ru}\left(\eta^{6}-N, N\right.\right.$-dimethylaniline $\left.)\left(\eta^{4}-1,5-\mathrm{COD}\right)\right] \quad(1 \mathrm{~d}) . \quad\left[\mathrm{Ru}\left(\eta^{6}-\right.\right.$ naphthalene $\left.)\left(\eta^{4}-1,5-C O D\right)\right] \quad(1 \mathrm{a}) \quad(203.8 \mathrm{mg}, 0.604 \mathrm{mmol})$ was treated with $\mathrm{MeCN}(1 \mathrm{~mL}, 20 \mathrm{mmol})$ and $N, N$-dimethylaniline (1 $\mathrm{mL}, 8 \mathrm{mmol})$ in THF $(10 \mathrm{~mL})$ at room temperature for $17 \mathrm{~h}$. After concentration of the solution, the product was purified by alumina chromatography using hexane and all volatile matter was removed under reduced pressure. Recrystallization of the resulting solid from cold hexane produced yellow plates of $\mathbf{1 d}$ ( $54 \%$ yield, $107.8 \mathrm{mg}, 0.326$ $\mathrm{mmol}$ ). ${ }^{1} \mathrm{H}$ NMR (400 MHz, $\left.\mathrm{C}_{6} \mathrm{D}_{6}\right): \delta 2.29$ (s, $6 \mathrm{H}, \mathrm{NMe}$ ), 2.35-2.48 $\left(\mathrm{m}, 8 \mathrm{H}, \mathrm{CH}_{2}\right.$ in $\left.\mathrm{COD}\right), 3.43\left(\mathrm{~d},{ }^{3} \mathrm{~J}_{\mathrm{H}-\mathrm{H}}=9.2 \mathrm{~Hz}, 4 \mathrm{H},=\mathrm{CH}\right.$ in COD), $4.46\left(\mathrm{~d},{ }^{3} J_{\mathrm{H}-\mathrm{H}}=5.7 \mathrm{~Hz}, 2 \mathrm{H}, 2-\mathrm{CH}\right.$ in aromatic ring $), 4.71-4.77(\mathrm{~m}$, $2 \mathrm{H}, 3-\mathrm{CH}$ in aromatic ring), $5.06\left(\mathrm{t},{ }^{3} \mathrm{~J}_{\mathrm{H}-\mathrm{H}}=5.7 \mathrm{~Hz}, 1 \mathrm{H}, 4-\mathrm{CH}\right.$ in aromatic ring $).{ }^{13} \mathrm{C}\left\{{ }^{1} \mathrm{H}\right\}$ NMR $\left(100 \mathrm{MHz}, \mathrm{C}_{6} \mathrm{D}_{6}\right): \delta 34.69\left(\mathrm{~s}, \mathrm{CH}_{2}\right.$ in $\mathrm{COD}$ ), 29.88 (s, Me), 58.78 (s, = CH in COD), 69.60 (s, arene), 82.22 (s, arene), 90.14 (s, arene), 130.16 (s, arene). Satisfactory elemental analysis data were not obtained, and this compound was characterized by spectroscopic methods.

[Ru $\left(\eta^{6}-1,2\right.$-dimethoxybenzene) $\left.\left(\eta^{4}-1,5-C O D\right)\right]$ (1f). Similar to the case for $\mathbf{1 d}, \mathbf{1}$ f was prepared by the reaction of $1 \mathrm{a}(203.2 \mathrm{mg}, 0.602$ $\mathrm{mmol}), \mathrm{MeCN}(1 \mathrm{~mL}, 20 \mathrm{mmol})$, and 1,2-dimethoxybenzene $(600 \mu \mathrm{L}$, $4.69 \mathrm{mmol})$ in THF $(16 \mathrm{~mL})$ at room temperature for 4 days. If was obtained as yellow plates (25\% yield, $53.1 \mathrm{mg}, 0.153 \mathrm{mmol}) .{ }^{1} \mathrm{H}$ NMR $\left(400 \mathrm{MHz}, \mathrm{C}_{6} \mathrm{D}_{6}\right): \delta 2.37-2.39\left(\mathrm{~m}, 8 \mathrm{H}, \mathrm{CH}_{2}\right.$ in $\left.\mathrm{COD}\right), 3.35(\mathrm{~s}, 6 \mathrm{H}$, $\mathrm{OMe}), 3.43(\mathrm{~m}, 4 \mathrm{H},=\mathrm{CH}$ in $\mathrm{COD}), 4.46(\mathrm{~s}, 2 \mathrm{H}$, aromatic $), 4.95(\mathrm{~s}$, $2 \mathrm{H}$, aromatic). ${ }^{13} \mathrm{C}\left\{{ }^{1} \mathrm{H}\right\} \mathrm{NMR}\left(100 \mathrm{MHz}, \mathrm{C}_{6} \mathrm{D}_{6}\right): \delta 34.57\left(\mathrm{~s}, \mathrm{CH}_{2}\right.$ in $\mathrm{COD}), 57.40(\mathrm{~s}, \mathrm{OMe}), 61.43$ ( $\mathrm{s},=\mathrm{CH}$ in $\mathrm{COD}), 72.88$ (s, arene), 83.35 (s, arene), 126.0 (s, arene). Anal. Calcd for $\mathrm{C}_{16} \mathrm{H}_{22} \mathrm{O}_{2} \mathrm{Ru}$ : C, 55.31; H, 6.38. Found: C, 55.31; H, 6.59.

[Ru $\left(\eta^{6}-1,3-\right.$ dimethoxybenzene) $\left.\left(\eta^{4}-1,5-C O D\right)\right](1 \mathrm{~g})$. Similar to the case for $1 \mathrm{~d}, 1 \mathrm{~g}$ was prepared by the reaction of $1 \mathrm{a}(106.2 \mathrm{mg}$, $0.315 \mathrm{mmol}), \mathrm{MeCN}(1 \mathrm{~mL}, 20 \mathrm{mmol})$, and 1,3-dimethoxybenzene $(150 \mu \mathrm{L}, 1.00 \mathrm{mmol})$ in THF $(10 \mathrm{~mL})$ at room temperature for $42 \mathrm{~h}$. $1 \mathrm{~g}$ was obtained as yellow plates $(25 \%$ yield, $51.4 \mathrm{mg}, 0.148 \mathrm{mmol})$. ${ }^{1} \mathrm{H}$ NMR (400 MHz, $\left.\mathrm{C}_{6} \mathrm{D}_{6}\right): \delta 2.37\left(\mathrm{~m}, 8 \mathrm{H}, \mathrm{CH}_{2}\right.$ in COD), 3.23 (s, $6 \mathrm{H}, \mathrm{OMe}), 3.40(\mathrm{~m}, 4 \mathrm{H},=\mathrm{CH}$ in $\mathrm{COD}), 4.03\left(\mathrm{t},{ }^{3} J_{\mathrm{H}-\mathrm{H}}=5.6 \mathrm{~Hz}, 1 \mathrm{H}\right.$, aromatic), $4.82\left(\mathrm{~d},{ }^{3} \mathrm{~J}_{\mathrm{H}-\mathrm{H}}=5.6 \mathrm{~Hz}, 2 \mathrm{H}\right.$, aromatic $), 4.96(\mathrm{~s}, 1 \mathrm{H}$, aromatic). ${ }^{13} \mathrm{C}\left\{{ }^{1} \mathrm{H}\right\}$ NMR $\left(100 \mathrm{MHz}, \mathrm{C}_{6} \mathrm{D}_{6}\right): \delta 34.64\left(\mathrm{~s}, \mathrm{CH}_{2}\right.$ in COD), 55.95 (s, OMe), 62.25 ( $\mathrm{s},=\mathrm{CH}$ in $\mathrm{COD}$ ), 67.54 (s, arene), 73.51 (s, arene), 74.36 (s, arene), 136.19 (s, arene). Anal. Calcd for $\mathrm{C}_{16} \mathrm{H}_{22} \mathrm{O}_{2} \mathrm{Ru}$ : C, 55.31; H, 6.38. Found: C, 55.39; H, 6.28.

[Ru( $\eta^{6}-1,4-$ dimethoxybenzene $\left.)\left(\eta^{4}-1,5-C O D\right)\right](1 \mathrm{~h})$. Similar to the case for $\mathbf{1 d}, \mathbf{1 h}$ was prepared by the reaction of $1 \mathrm{a}(199.2 \mathrm{mg}$, $0.590 \mathrm{mmol}), \mathrm{MeCN}(2 \mathrm{~mL}, 40 \mathrm{mmol})$, and 1,4-dimethoxybenzene $(297.5 \mu \mathrm{L}, 2.153 \mathrm{mmol})$ in THF $(15 \mathrm{~mL})$ at room temperature for 2 days. 1h was obtained as yellow plates ( $67 \%$ yield, $136.5 \mathrm{mg}, 0.392$ mmol). ${ }^{1} \mathrm{H}$ NMR $\left(400 \mathrm{MHz}, \mathrm{C}_{6} \mathrm{D}_{6}\right): \delta 2.37-2.42\left(\mathrm{~m}, 8 \mathrm{H}, \mathrm{CH}_{2}\right.$ in $\mathrm{COD}), 3.25(\mathrm{~s}, 6 \mathrm{H}, \mathrm{OMe}), 3.35(\mathrm{~m}, 4 \mathrm{H},=\mathrm{CH}$ in $\mathrm{COD}), 4.62(\mathrm{~s}, 4 \mathrm{H}$, aromatic). ${ }^{13} \mathrm{C}\left\{{ }^{1} \mathrm{H}\right\}$ NMR $\left(100 \mathrm{MHz}, \mathrm{C}_{6} \mathrm{D}_{6}\right): \delta 34.86\left(\mathrm{~s}, \mathrm{CH}_{2}\right.$ in $\mathrm{COD}), 55.50(\mathrm{~s}, \mathrm{OMe}), 63.55(\mathrm{~s},=\mathrm{CH}$ in $\mathrm{COD}), 70.08$ (s, arene), 136.62 (s, arene). Satisfactory elemental analysis data were not obtained, and this compound was characterized by spectroscopic methods.

Synthesis of $\left[\mathrm{RuCl}_{2}\left(\eta^{6} \text {-anisole }\right)\right]_{2}(5 \mathrm{c})$. Method $A$. According to the literature method, ${ }^{31} \mathrm{RuCl}_{3} \cdot 3 \mathrm{H}_{2} \mathrm{O}(2.054 \mathrm{~g}, 7.8955 \mathrm{mmol})$ was dissolved in methanol $(80 \mathrm{~mL})$ and 1-methoxy-1,4-cyclohexadiene $(5.4 \mathrm{~mL}, 39.59 \mathrm{mmol})$ was added. The reaction mixture was refluxed for $24 \mathrm{~h}$ to give a brown precipitate. The product was obtained by extraction with a Soxhlet extraction apparatus with hot chloroform of the initially formed, poorly soluble green-brown solid and isolated as a green-brown solid by evaporation of the chloroform in $17 \%$ crude yield $(378 \mathrm{mg}, 0.65 \mathrm{mmol})$. The ${ }^{1} \mathrm{H}$ NMR spectrum of the obtained green-brown solid in DMSO- $d_{6}$ indicated it to be a mixture of $5 \mathrm{c}$ (89\%) and $\mathbf{5 b}(11 \%)$. Data for $\mathbf{5} \mathbf{c}$ are as follows. ${ }^{1} \mathrm{H}$ NMR $(400 \mathrm{MHz}$, $22.2{ }^{\circ} \mathrm{C}$, DMSO- $\left.d_{6}\right): \delta 3.90(\mathrm{~s}, 6 \mathrm{H}, \mathrm{OMe}), 5.36\left(\mathrm{t},{ }^{3} J_{\mathrm{H}-\mathrm{H}}=4.3 \mathrm{~Hz}, 2 \mathrm{H}\right.$, arene), $5.53\left(\mathrm{~d},{ }^{3} \mathrm{~J}_{\mathrm{H}-\mathrm{H}}=5.2 \mathrm{~Hz}, 4 \mathrm{H}\right.$, arene $), 6.15\left(\mathrm{t},{ }^{3} J_{\mathrm{H}-\mathrm{H}}=4.9 \mathrm{~Hz}\right.$, $4 \mathrm{H}$, arene). Typical analytical data of two different batches of this compound made in Kyoto and Canberra are as follows Found: C, $26.99,27.03 ; \mathrm{H}, 2.50,2.68 ; \mathrm{N}, 0,<0.3 ; \mathrm{Cl}, 28.18,27.86$. A sample of the solid that had not been extracted with chloroform but only dried in vacuo was analyzed as follows. Found: C, 25.59; H, 2.53; Cl, 28.28 . Calcd for $\mathrm{C}_{7} \mathrm{H}_{8} \mathrm{Cl}_{2} \mathrm{ORu}$ : C, 30.02; $\mathrm{H}, 2.88 ; \mathrm{N}, 0 ; \mathrm{Cl}, 25.31$. Calcd for $\mathrm{C}_{7} \mathrm{H}_{8} \mathrm{Cl}_{2} \mathrm{ORu} \cdot 0.22 \mathrm{RuCl}_{2}$ : C, 26.44; $\mathrm{H}, 2.54 ; \mathrm{Cl}, 27.21$.

Method $B$. According to the literature method, ${ }^{24}\left[\mathrm{Ru}\left(\eta^{6}\right.\right.$-anisole $)$ $\left.\left(\eta^{4}-1,5-\mathrm{COD}\right)\right]$ (1c) was prepared by the reaction of $\left[\mathrm{Ru}\left(\eta^{6}\right.\right.$. naphthalene $\left.)\left(\eta^{4}-1,5-\mathrm{COD}\right)\right]$ (1a) $(264.2 \mathrm{mg}, 0.7839 \mathrm{mmol})$ with excess anisole $(4.6041 \mathrm{~g}, 42.63 \mathrm{mmol})$ in the presence of $\mathrm{MeCN}(60$ $\mu \mathrm{L}, 0.952 \mathrm{mmol}$ ) at room temperature for 2 days (96\% yield, 239.5 $\mathrm{mg}, 0.756 \mathrm{mmol})$. Following the procedure of ref 29 , this was dissolved in acetone $(5 \mathrm{~mL})$ and $\mathrm{HCl}(36 \mathrm{M}, 0.20 \mathrm{~mL}, 7.2 \mathrm{mmol})$ was added to the solution at room temperature. An orange-brown precipitate deposited immediately. The dark red supernatant was removed by cannula, and the resulting orange powder was washed twice with acetone $(2 \mathrm{~mL})$ and dried under vacuum (83\% yield based on $\mathrm{Ru}, 175.1 \mathrm{mg}, 0.3127 \mathrm{mmol}) .{ }^{1} \mathrm{H}$ NMR $\left(400 \mathrm{MHz}, 22.3{ }^{\circ} \mathrm{C}\right.$, DMSO- $\left.d_{6}\right): \delta 3.29(\mathrm{~s}, \mathrm{OMe}), 5.38\left(\mathrm{t},{ }^{3} J_{\mathrm{H}-\mathrm{H}}=5.4 \mathrm{~Hz}, 1 \mathrm{H}, P h\right), 5.54(\mathrm{~d}$, $\left.{ }^{3} J_{\mathrm{H}-\mathrm{H}}=5.7 \mathrm{~Hz}, 2 \mathrm{H}, P h\right), 6.17\left(\mathrm{t},{ }^{3} J_{\mathrm{H}-\mathrm{H}}=5.7 \mathrm{~Hz}, 2 \mathrm{H}, P h\right)$. Anal. Calcd for $\mathrm{C}_{7} \mathrm{H}_{8} \mathrm{Cl}_{2} \mathrm{ORu}$ : C, 30.02; H, 2.88; N, 0. Found: C, 30.38; H, 2.61; N, 0.22 .

Synthesis of [Ru( $\eta^{6}$-anisole) $\left.\left(\eta^{4}-1,5-C O D\right)\right]$ (1c) by Use of 5c. A crude mixture of $\mathbf{5 c}$ and $\mathbf{5 b}(91 \mathrm{mg}, 0.15 \mathrm{mmol}, \mathbf{5 c} / \mathbf{5 b}=89 / 11)$ and $\mathrm{Na}_{2} \mathrm{CO}_{3}(160 \mathrm{mg}, 1.52 \mathrm{mmol})$ was dissolved in 2-propanol $(10 \mathrm{~mL})$, and 1,5-COD $(1 \mathrm{~mL}, 8 \mathrm{mmol})$ was added to the solution. After the solution was heated to $100{ }^{\circ} \mathrm{C}$ for $30 \mathrm{~min}$, it was concentrated and purified by alumina column chromatography with THF. The yellow fraction was evaporated under reduced pressure to give a brown oil (72 mg). The ${ }^{1} \mathrm{H}$ NMR analysis suggested formation of $1 \mathrm{c}$ (60\% yield) as an inseparable mixture with $\mathbf{1 b}$ ( $8 \%$ yield).

Cross-Dimerization of 2,3-Dimethylbutadiene with Styrene Catalyzed by $\left[\mathrm{RuCl}_{2}\left(\eta^{6} \text {-anisole }\right)\right]_{2}$ (5c). Complex 5c $(21.07 \mathrm{mg}$, $0.376 \mathrm{mmol}$ ), $\mathrm{Na}_{2} \mathrm{CO}_{3}$ (32.04 $\mathrm{mg}, 0.302 \mathrm{mmol}$ ), and dibenzyl (45.07 $\mathrm{mg}, 0.251 \mathrm{mmol}$ ) as an internal standard were dissolved in 2-butanol $(2 \mathrm{~mL})$, and 1,5-COD $(20 \mu \mathrm{L}, 0.15 \mathrm{mmol})$ was added to the solution. After the mixture was heated to $100{ }^{\circ} \mathrm{C}$ for $1 \mathrm{~h}$, to the solution at room temperature were added 2,3-dimethylbutadiene $(100 \mu \mathrm{L}, 0.88 \mathrm{mmol})$ and styrene $(86 \mu \mathrm{L}, 0.75 \mathrm{mmol})$ in an autoclave. The reaction mixture was heated at $100{ }^{\circ} \mathrm{C}$ for $6 \mathrm{~h}$, during which the reaction course was monitored by GLC: $62 \%$ total yield, $3 \mathbf{a} / 3 \mathbf{b} /$ isomers $=24 / 40 / 36$. Similar experiments were performed. $5 \mathbf{c}(21.2 \mathrm{mg}, 0.0378 \mathrm{mmol})$, $\mathrm{Na}_{2} \mathrm{CO}_{3}$ (16.1 mg, $\left.0.152 \mathrm{mmol}\right)$ 2-propanol (2 mL), 1,5-COD (20 $\mu \mathrm{L}$, $0.152 \mathrm{mmol}), 2,3$-dimethylbutadiene $(100 \mu \mathrm{L}, 0.88 \mathrm{mmol})$, and styrene $(86 \mu \mathrm{L}, 0.75 \mathrm{mmol})$ in Schlenk tube: $8 \%$ total yield, $3 \mathbf{a} / \mathbf{3 b} /$ isomers $=12 / 50 / 38.5 \mathrm{c}(20.8 \mathrm{mg}, 0.0371 \mathrm{mmol}), \mathrm{Na}_{2} \mathrm{CO}_{3}(16.0 \mathrm{mg}$, $0.151 \mathrm{mmol})$, 2-propanol $(2 \mathrm{~mL}), 1,5-\mathrm{COD}(20 \mu \mathrm{L}, 0.152 \mathrm{mmol}), 2,3-$ dimethylbutadiene $(100 \mu \mathrm{L}, 0.88 \mathrm{mmol})$, and styrene $(86 \mu \mathrm{L}, 0.75$ 
$\mathrm{mmol}$ ) in autoclave: $47 \%$ total yield, $3 \mathrm{a} / 3 \mathbf{b} /$ isomers $=21 / 43 / 36.5 \mathrm{c}$ (21.1 mg, $0.0377 \mathrm{mmol}), \mathrm{Na}_{2} \mathrm{CO}_{3}(32.0 \mathrm{mg}, 0.302 \mathrm{mmol}), 2$-propanol $(2 \mathrm{~mL}), 1,5-\mathrm{COD}(20 \mu \mathrm{L}, 0.15 \mathrm{mmol}), 2,3$-dimethylbutadiene (100 $\mu \mathrm{L}, 0.88 \mathrm{mmol})$, and styrene $(86 \mu \mathrm{L}, 0.75 \mathrm{mmol})$ in autoclave: $55 \%$ total yield, $3 \mathbf{a} / 3 \mathbf{b} /$ isomers $=16 / 47 / 36.5 \mathbf{c}(20.9 \mathrm{mg}, 0.0373 \mathrm{mmol})$, $\mathrm{Na}_{2} \mathrm{CO}_{3}$ (31.9 mg, $\left.0.301 \mathrm{mmol}\right), 2$-propanol $(2 \mathrm{~mL}), 1,5-\mathrm{COD}(40$ $\mu \mathrm{L}, 0.30 \mathrm{mmol}), 2,3$-dimethylbutadiene $(31.7 \mathrm{mg}, 0.299 \mathrm{mmol})$, DMSO (2 mL), 1,5-COD (20 $\mu \mathrm{L}, 0.15 \mathrm{mmol}), 2,3$-dimethylbutadiene $(100 \mu \mathrm{L}, 0.88 \mathrm{mmol})$, and styrene $(86 \mu \mathrm{L}, 0.75 \mathrm{mmol})$ in a Schlenk tube: $1 \%$ yield. $5 \mathrm{c}(20.9 \mathrm{mg}, 0.0373 \mathrm{mmol}), \mathrm{Na}_{2} \mathrm{CO}_{3}(30.2 \mathrm{mg}, 0.289$ $\mathrm{mmol})$, 1-butanol $(2 \mathrm{~mL}), 1,5-\mathrm{COD}(20 \mu \mathrm{L}, 0.15 \mathrm{mmol}), 2,3-$ dimethylbutadiene $(100 \mu \mathrm{L}, 0.88 \mathrm{mmol})$, and styrene $(86 \mu \mathrm{L}, 0.75$ $\mathrm{mmol})$ in a Schlenk tube: $1 \%$ yield. $5 \mathrm{c}(21.1 \mathrm{mg}, 0.0376 \mathrm{mmol})$, $\mathrm{Na}_{2} \mathrm{CO}_{3}(32.0 \mathrm{mg}, 0.302 \mathrm{mmol}), 2$-butanol $(2 \mathrm{~mL}), 1,5-\mathrm{COD}(20 \mu \mathrm{L}$, $0.15 \mathrm{mmol}), 2,3$-dimethylbutadiene $(100 \mu \mathrm{L}, 0.88 \mathrm{mmol})$, and styrene $(86 \mu \mathrm{L}, 0.75 \mathrm{mmol})$ in a Schlenk tube: $62 \%$ total yield, $3 \mathrm{a} / 3 \mathbf{b} /$ isomers $=24 / 40 / 36.5 \mathrm{c}(21.0 \mathrm{mg}, 0.0375 \mathrm{mmol}), \mathrm{Na}_{2} \mathrm{CO}_{3}(31.8 \mathrm{mg}, 0.300$ mmol), 2-butanol (2 mL), 2,3-dimethylbutadiene (100 $\mu \mathrm{L}, 0.88$ $\mathrm{mmol})$, and styrene $(86 \mu \mathrm{L}, 0.75 \mathrm{mmol})$ in a Schlenk tube: $0 \%$ yield. 6c $(21.5 \mathrm{mg}, 0.00656 \mathrm{mmol}), \mathrm{Na}_{2} \mathrm{CO}_{3}(31.9 \mathrm{mg}, 0.301 \mathrm{mmol}), 2-$ propyl alcohol $(2 \mathrm{~mL}), 1,5-\mathrm{COD}(20 \mu \mathrm{L}, 0.15 \mathrm{mmol}), 2,3-$ dimethylbutadiene $(100 \mu \mathrm{L}, 0.88 \mathrm{mmol})$, and styrene $(86 \mu \mathrm{L}, 0.75$ $\mathrm{mmol}$ ) in autoclave: $45 \%$ total yield, $3 \mathbf{a} / \mathbf{3 b} /$ isomers $=18 / 44 / 38$.

X-ray Analyses. A single crystal was selected using a polarized microscope and was mounted on a glass capillary by use of Paratone-N oil. A Rigaku AFC-7R Mercury II diffractometer with graphitemonochromated Mo $\mathrm{K} \alpha$ radiation $(\lambda=0.71075 \AA)$ was used for data collection. The collected data were solved by direct methods and refined by a full-matrix least-squares procedure using the CrystalStructure program (ver. 4.2). ${ }^{40,41}$ All hydrogen atoms were treated as a riding model. The optimized structures are depicted by use of the POV-Ray program (ver. 3.6.2). ${ }^{42}$ Incorporation of THF and $5 \mathrm{H}$ dibenzo[b.f]azepine molecules were observed in a unit cell of $\mathbf{2 d}$. CCDC 1567421, 1567423, 1567422, 1567420, 1567419, and 1567438 contain the supplementary crystallographic data for $\mathbf{1 d}, \mathbf{g}, \mathbf{h}$ and $\mathbf{2 b}-\mathbf{d}$, respectively.

\section{ASSOCIATED CONTENT}

\section{S Supporting Information}

The Supporting Information is available free of charge on the ACS Publications website at DOI: 10.1021/acs.organomet.7b00882.

Screening data of the catalysts and catalyses, NMR data of new complexes $\mathbf{1 d}, \mathbf{f}-\mathbf{h}$, and $\mathbf{2} \mathbf{b}-\mathbf{d}$, and crystallographic data for $\mathbf{1 d}, \mathbf{g}, \mathbf{h}$ and $\mathbf{2 b}-\mathbf{d}$ (PDF)

\section{Accession Codes}

CCDC 1567419-1567423 and 1567438 contain the supplementary crystallographic data for this paper. These data can be obtained free of charge via www.ccdc.cam.ac.uk/data_request/ cif, or by emailing data_request@ccdc.cam.ac.uk, or by contacting The Cambridge Crystallographic Data Centre, 12 Union Road, Cambridge CB2 1EZ, UK; fax: +44 1223336033.

\section{AUTHOR INFORMATION}

\section{Corresponding Authors}

*E-mail for M.H.: hrc@cc.tuat.ac.jp.

*E-mail for M.A.B.: martin.a.bennett@anu.edu.au.

\section{ORCID $\odot$}

Masafumi Hirano: 0000-0001-7835-1044

Nobuyuki Komine: 0000-0003-1744-695X

Annie L. Colebatch: 0000-0001-6920-3744

\section{Present Address}

${ }^{\S}$ Department of Chemistry, The University of Cambridge, Lensfield Road, Cambridge CB2 1EW, U.K.

\section{Notes}

The authors declare no competing financial interest.

\section{ACKNOWLEDGMENTS}

We thank Prof. M. Akita and Dr. Y. Tanaka (Tokyo Institute of Technology) for MALDI-TOF MS analyses and Dr. S. Kiyota for elemental analyses. We also thank the Campbell microanalytical laboratory at the University of Otago, Otago, New Zealand. A part of this work was financially supported by the Japan Science and Technology Agency (JST), ACT-C (JPMJCR12Z2), and a part of this work was also supported by a JSPS Grant-in-Aid for Scientific Research on Innovative Areas "3D Active-Site Science" (26105003).

\section{ABBREVIATIONS}

COD,cyclooctadiene $\left(\mathrm{C}_{8} \mathrm{H}_{12}\right)$; COT,cyclooctatriene $\left(\mathrm{C}_{8} \mathrm{H}_{10}\right)$; DMA,dimethylacetamide $\left(\mathrm{C}_{4} \mathrm{H}_{9} \mathrm{ON}\right)$; acac,acetylacetonate $\left(\mathrm{C}_{5} \mathrm{H}_{7} \mathrm{O}_{2}\right) ; \mathrm{Cp}^{*}$,pentamethylcyclopentadienyl $\left(\mathrm{C}_{10} \mathrm{H}_{15}\right)$; THF,tetrahydrofuran $\left(\mathrm{C}_{4} \mathrm{H}_{8} \mathrm{O}\right)$; dcype, 1,2-bis (dicyclohexylphosphino)ethane $\left(\mathrm{C}_{26} \mathrm{H}_{48} \mathrm{P}_{2}\right)$; DMSO,dimethyl sulfoxide $\left(\mathrm{C}_{3} \mathrm{H}_{6} \mathrm{OS}\right)$; Schmalzphos, $(3 \mathrm{aR}, 8 \mathrm{a} R)-6-((3-$ (diphenylphosphaneyl)[1,1'-biphenyl]-2-yl)oxy)-2,2-dimethyl4,4,8,8-tetraphenyltetrahydro- $[1,3]$ dioxolo $[4,5-e][1,3,2]$ dioxaphosphepine $\left(\mathrm{C}_{55} \mathrm{H}_{46} \mathrm{O}_{5} \mathrm{P}_{2}\right)$

\section{REFERENCES}

(1) Wittenberg, D. Angew. Chem. 1963, 75, 1124.

(2) Cros, P.; Triantaphylides, C.; Buono, G. J. Org. Chem. 1988, 53, 185-187.

(3) Hattori, S.; Tatsuoka, K. Ger. Pat. DE2104626, 1971

(4) Ito, T.; Takahashi, K.; Takami, Y. Tetrahedron Lett. 1973, 14, 5049-5050.

(5) (a) Bönnemann, H.; Grard, C.; Kopp, W.; Pump, W.; Tanaka, K.; Wilke, G. Angew. Chem., Int. Ed. Engl. 1973, 12, 964-975. (b) Bönnemann, H.; Grard, C.; Kopp, W.; Wilke, G. Int. Congr. Pure Appl. Chem. 1971, 6, 265.

(6) (a) Auvinet, A.-L.; Harrity, J. P. A.; Hilt, G. J. Org. Chem. 2010, 75, 3893-3896.

(7) Hilt, G.; Danz, M. Synthesis 2008, 2008, 2257-2263.

(8) Jing, S. M.; Balasanthiran, V.; Pagar, V.; Gallucci, J. C.; RajanBabu, T. V. J. Am. Chem. Soc. 2017, 139, 18034-18043.

(9) Bochmann, M.; Thomas, M. J. Mol. Catal. 1984, 26, 79-88.

(10) Misono, A.; Uchida, Y.; Saito, T.; Uchida, K. Bull. Chem. Soc. Jpn. 1967, 40, 1889-1893.

(11) (a) Mitsudo, T.; Zhang, S.-W.; Kondo, T.; Watanabe, Y. Tetrahedron Lett. 1992, 33, 341-344. Related selected papers: (b) Ura, Y.; Tsujita, H.; Wada, K.; Kondo, T.; Mitsudo, T. J. Org. Chem. 2005, 70, 6623-6628. Tsujita, H.; Ura, Y.; Wada, K.; Kondo, T.; Mitsudo, T. Chem. Commun. 2005, 5100-5102. (d) Tsujita, H.; Ura, Y.; Matsuki, S.; Wada, K.; Mitsudo, T.; Kondo, T. Angew. Chem., Int. Ed. 2007, 46, 5160-5163. (e) Kondo, T.; Takagi, D.; Tsujita, H.; Ura, Y.; Wada, K.; Mitsudo, T. Angew. Chem., Int. Ed. 2007, 46, 59585961.

(12) Fujiwhara, M.; Nishikawa, T.; Hori, Y. Org. Lett. 1999, 1, 16351637.

(13) Moreau, B.; Wu, J. Y.; Ritter, T. Org. Lett. 2009, 11, 337-339.

(14) Fukuzawa, H.; Aoyagi, N.; Sato, R.; Kataoka, Y.; Ura, Y. Organometallics 2017, 36, 3931-3939.

(15) Simon, M.-O.; Darses, S. J. Org. Chem. 2013, 78, 9981-9985.

(16) Hirano, M.; Komiya, S. Coord. Chem. Rev. 2016, 314, 182-200.

(17) Hirano, M.; Arai, Y.; Hamamura, Y.; Komine, N.; Komiya, S. Organometallics 2012, 31, 4006-4019.

(18) (a) Pertici, P.; Ballantini, V.; Salvadori, P.; Bennett, M. A. Organometallics 1995, 14, 2565-2569. (b) Hirano, M.; Sakate, Y.; Komine, N.; Komiya, S.; Bennett, M. A. Organometallics 2009, 28, 
4902-4905. (c) Hirano, M.; Hiroi, Y.; Komine, N.; Komiya, S. Organometallics 2010, 29, 3690-3693.

(19) (a) Hiroi, Y.; Komine, N.; Hirano, M.; Komiya, S. Organometallics 2011, 30, 1307-1310. (b) Hiroi, Y.; Komine, N.; Komiya, S.; Hirano, M. Org. Lett. 2013, 15, 2486-2489. (c) Hirano, M.; Moritake, M.; Murakami, T.; Komine, N. Chem. Lett. 2017, 46, 1522-1524.

(20) (a) Hirano, M.; Ueda, T.; Komine, N.; Komiya, S.; Nakamura, S.; Deguchi, H.; Kawauchi, S. J. Organomet. Chem. 2015, 797, 174184. (b) Hirano, M.; Sakate, Y.; Komine, N.; Komiya, S.; Wang, X.-Q.; Bennett, M. A. Organometallics 2011, 30, 768-777.

(21) (a) Bennett, M. A.; Byrnes, M. J.; Willis, A. C. Organometallics 2003, 22, 1018-1028. (b) Bennett, M. A.; Byrnes, M. J.; Kovácik, I. J. Organomet. Chem. 2004, 689, 4463-4474. (c) Hiroi, Y.; Komine, N.; Komiya, S.; Hirano, M. Organometallics 2014, 33, 6604-6613.

(22) Rieke, R. D. Science 1989, 246, 1260-1264.

(23) Bennett, M. A.; Chung, G.; Hockless, D. C. R.; Neumann, H.; Willis, A. C. J. Chem. Soc., Dalton Trans. 1999, 3451-3462.

(24) (a) Bennett, M. A.; Neumann, H.; Thomas, M.; Wang, X.-Q.; Pertici, P.; Salvadori, P.; Vitulli, G. Organometallics 1991, 10, 32373245. Vitulli, G.; Pertici, P.; Salvadori, P. J. Chem. Soc., Dalton Trans. 1984, 2255-2257.

(25) Bennett, M. A.; McMahon, I. J.; Pelling, S.; Brookhart, M.; Lincoln, D. M. Organometallics 1992, 11, 127-138.

(26) (a) Bennett, M. A.; Matheson, T. W. J. Organomet. Chem. 1978, 153, C25-27. (b) One can refer to the detailed description of the following procedure for the $\left[\mathrm{Ru}\left(\mathrm{C}_{6} \mathrm{Me}_{6}\right) \mathrm{L}\right]$ analogues: Bennett, $\mathrm{M}$. A.; Huang, T.-N.; Matheson, T. W.; Smith, A. K. Inorg. Synth. 2007, 21, 74-78.

(27) Katayama, H.; Nagao, M.; Ozawa, F. Organometallics 2003, 22, 586-593.

(28) Pertici, P.; Bertozzi, S.; Lazzaroni, R.; Vitulli, G.; Bennett, M. A. J. Organomet. Chem. 1988, 354, 117-122.

(29) Pertici, P.; Vitulli, G.; Lazzaroni, R.; Salvadori, P.; Barili, P. L. J. Chem. Soc., Dalton Trans. 1982, 1019-1022.

(30) Schmid, H.; Ziegler, M. L. Chem. Ber. 1976, 109, 132-138.

(31) Bennett, M. A.; Smith, A. K. J. Chem. Soc., Dalton Trans. 1974, 233-241.

(32) Soleimannejad, J.; White, C. Organometallics 2005, 24, 25382541.

(33) Iwata, R.; Ogata, I. Tetrahedron 1973, 29, 2753-2758.

(34) Knowles, T. S.; Howells, M. E.; Howlin, B. J.; Smith, G. W.; Amodio, C. A. Polyhedron 1994, 13, 2197-2203.

(35) Itoh, K.; Nagashima, H.; Ohshima, T.; Oshima, N.; Nishiyama, N. J. Organomet. Chem. 1984, 272, 179-188.

(36) Powell, P. J. Organomet. Chem. 1974, 65, 89-92.

(37) Callander, D. D.; Coe, P. L.; Tatlow, J. C.; Uff, A. J. Tetrahedron

1969, 25, 25-35.

(38) Roggen, M.; Carreira, E. M. Angew. Chem., Int. Ed. 2011, 50, $5568-5571$.

(39) Burt, R. J.; Chatt, J.; Hussain, W.; Leigh, G. J. J. Organomet. Chem. 1979, 182, 203-206.

(40) Crystalstructure ver.4.2; Rigaku Corporation, Tokyo, Japan, 2015. (41) Sheldrick, G. M. SHELXL97; University of Göttingen, Göttingen, Germany, 1997.

(42) POV-Ray for windows ver. 3.6.2; Persistence of Vision Ray Tracer Pty, Ltd. 